\title{
Interannual variation, decadal trend, and future change in ozone outflow from East Asia
}

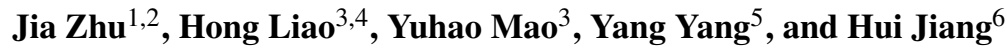 \\ ${ }^{1}$ State Key Laboratory of Atmospheric Boundary Layer Physics and Atmospheric Chemistry (LAPC), Institute of \\ Atmospheric Physics, Chinese Academy of Sciences, Beijing, China \\ ${ }^{2}$ University of Chinese Academy of Sciences, Beijing, China \\ ${ }^{3}$ School of Environmental Science and Engineering, Nanjing University of Information Science \& \\ Technology, Nanjing, China \\ ${ }^{4}$ International Joint Laboratory on Climate and Environmental Change, Nanjing University of Information \\ Science \& Technology, Nanjing, China \\ ${ }^{5}$ Atmospheric Sciences \& Global Change, Pacific Northwest National Laboratory, Richland, Washington, USA \\ ${ }^{6}$ National Meteorological Information Center, China Meteorological Administration, Beijing, China
}

Correspondence to: Hong Liao (hongliao@ nuist.edu.cn)

Received: 20 October 2016 - Discussion started: 1 November 2016

Revised: 26 February 2017 - Accepted: 2 March 2017 - Published: 17 March 2017

\begin{abstract}
We examine the past and future changes in the $\mathrm{O}_{3}$ outflow from East Asia using a global 3-D chemical transport model, GEOS-Chem. The simulations of Asian $\mathrm{O}_{3}$ outflow for 1986-2006 are driven by the assimilated GEOS-4 meteorological fields, and those for 2000-2050 are driven by the meteorological fields archived by the NASA Goddard Institute for Space Studies (GISS) general circulation model (GCM) 3 under the IPCC SRES A1B scenario. The evaluation of the model results against measurements shows that the GEOS-Chem model captures the seasonal cycles and interannual variations of tropospheric $\mathrm{O}_{3}$ concentrations fairly well with high correlation coefficients of $0.82-0.93$ at four ground-based sites and $0.55-0.88$ at two ozonesonde sites where observations are available. The increasing trends in surface-layer $\mathrm{O}_{3}$ concentrations in East Asia over the past 2 decades are captured by the model, although the modeled $\mathrm{O}_{3}$ trends have low biases. Sensitivity studies are conducted to examine the respective impacts of meteorological parameters and emissions on the variations in the outflow flux of $\mathrm{O}_{3}$. When both meteorological parameters and anthropogenic emissions varied from 1986-2006, the simulated Asian $\mathrm{O}_{3}$ outflow fluxes exhibited a statistically insignificant decadal trend; however, they showed large interannual variations (IAVs) with seasonal values of 4-9\% for the absolute percent departure from the mean (APDM) and an annual
\end{abstract}

APDM value of $3.3 \%$. The sensitivity simulations indicated that the large IAVs in $\mathrm{O}_{3}$ outflow fluxes were mainly caused by variations in the meteorological conditions. The variations in meteorological parameters drove the IAVs in $\mathrm{O}_{3}$ outflow fluxes by altering the $\mathrm{O}_{3}$ concentrations over East Asia and by altering the zonal winds; the latter was identified to be the key factor, since the $\mathrm{O}_{3}$ outflow was highly correlated with zonal winds from 1986-2006. The simulations of the 2000-2050 changes show that the annual outflow flux of $\mathrm{O}_{3}$ will increase by $2.0,7.9$, and $12.2 \%$ owing to climate change alone, emissions change alone, and changes in both climate and emissions, respectively. Therefore, climate change will aggravate the effects of the increases in anthropogenic emissions on future changes in the Asian $\mathrm{O}_{3}$ outflow. Future climate change is predicted to greatly increase the Asian $\mathrm{O}_{3}$ outflow in the spring and summer seasons as a result of the projected increases in zonal winds. The findings from the present study help us to understand the variations in tropospheric $\mathrm{O}_{3}$ in the downwind regions of East Asia on different timescales and have important implications for long-term air quality planning in the regions downwind of China, such as Japan and the US. 


\section{Introduction}

Tropospheric ozone $\left(\mathrm{O}_{3}\right)$ is an important air pollutant that has a detrimental effect on human health (Fann et al., 2012; Jhun et al., 2014), crops (Wilkinson et al., 2011; Tai et al., 2014), and ecosystems (Fuentes et al., 2013; Yue and Unger, 2014). It is also an important greenhouse gas that directly contributes to global warming (IPCC, 2013). $\mathrm{O}_{3}$ has a relatively long lifetime of weeks in the free troposphere (Young et al., 2013; Monks et al., 2015), which makes the intercontinental transport of $\mathrm{O}_{3}$ an important issue for understanding $\mathrm{O}_{3}$ concentrations and planning emission control measures.

A number of previous studies have shown that Asian continental outflow impacts the global $\mathrm{O}_{3}$ budget (Liu et al., 2002) and influences $\mathrm{O}_{3}$ air quality in the downwind regions from the western North Pacific to western North America (Jacob et al., 1999; Tanimoto et al., 2005; Kim et al., 2006; Li et al., 2008; Zhang et al., 2008; Chiang et al., 2009; Kurokawa et al., 2009; Huang et al., 2010; Nagashima et al., 2010; Walker et al., 2010; Ambrose et al., 2011; Lin et al., 2012; OuYang et al., 2013; Han et al., 2015; Pochanart et al., 2015). Liu et al. (2002) reported that boundary-layer $\mathrm{O}_{3}$ pollution was lifted into the upper troposphere by deep convection over the Asian maritime continent. From there, it was transported northward along the upper branch of the local Hadley circulation and into the mid-latitude westerlies, influencing the global $\mathrm{O}_{3}$ budget. Using a global 3-D chemical transport model, GEOS-Chem, Zhang et al. (2008) estimated that Asian pollution enhanced surface-layer $\mathrm{O}_{3}$ concentrations by 5-7 ppbv over western North America in spring 2006. Walker et al. (2010) used the same model (GEOS-Chem) to evaluate the sensitivities of tropospheric $\mathrm{O}_{3}$ over Canada to Asian anthropogenic emissions and reported that the contribution from Asian emissions to $\mathrm{O}_{3}$ profiles above Whistler, Canada was 6-8 ppbv in spring 2006. Through an integrated analysis of in situ and satellite measurements in May-June 2010 with a global chemistry-climate model, GFDL AM3, Lin et al. (2012) reported that Asian emissions could contribute $8-15$ ppbv of $\mathrm{O}_{3}$ over the western United States on days when the observed daily maximum $8 \mathrm{~h}$ average of $\mathrm{O}_{3}$ (MDA8 $\mathrm{O}_{3}$ ) exceeded $60 \mathrm{ppbv}$. They also reported that $20 \%$ of MDA8 $\mathrm{O}_{3}$ exceedances of $60 \mathrm{ppbv}$ would not have occurred in the southwestern United States in the absence of Asian anthropogenic emissions.

Asian $\mathrm{O}_{3}$ outflow exhibits seasonal variations (Liu et al., 2002; Han et al., 2015). Using a global 3-D chemical transport model, GEOS-Chem, Liu et al. (2002) simulated the seasonal variations in the Asian outflow flux of $\mathrm{O}_{3}$ over the $\mathrm{Pa}$ cific, which was defined as the eastward flux integrated for the tropospheric column through a wall located at $150^{\circ} \mathrm{E}$ between 10 and $60^{\circ} \mathrm{N}$. They found that the Asian $\mathrm{O}_{3}$ outflow flux reached a maximum in early spring (March) and a minimum in summer (July). Han et al. (2015) examined $\mathrm{O}_{3}$ measurements at the Ieodo Ocean Research Station located in the East China Sea, which is regarded as an ideal place to ob- serve Asian outflow without local effects. They reported that the seasonal variation in $\mathrm{O}_{3}$ was distinct, with a minimum in August and two peaks in April and October, and was greatly affected by the seasonal wind pattern over East Asia.

The continental outflow of $\mathrm{O}_{3}$ is expected to vary on interannual to decadal timescales because tropospheric $\mathrm{O}_{3}$ concentrations and meteorological parameters have variations on these timescales. Large interannual variations (IAVs) in tropospheric $\mathrm{O}_{3}$ concentrations have been reported in previous observational studies (Kurokawa et al., 2009; Zhou et al., 2013). After analyzing 11 years of ozonesonde data over Hong Kong, Zhou et al. (2013) reported that observed tropospheric $\mathrm{O}_{3}$ levels from 2000-2010 exhibited high IAVs with an annual averaged amplitude [defined as (maximum + 2nd maximum - minimum -2 nd minimum) $\times 0.5 /$ the average from 2000-2010] of up to $30 \%$ of the averaged concentrations at 3-8 km of altitude. Kurokawa et al. (2009) analyzed observed springtime $\mathrm{O}_{3}$ over Japan from 1985-2005 and found that the observed $\mathrm{O}_{3}$ showed greater year-to-year variations than the annual rate of the long-term trend. The decadal trends in tropospheric $\mathrm{O}_{3}$ concentrations have been reported for different locations on the basis of observations (Ding et al., 2008a; Xu et al., 2008; Tang et al., 2009; Tanimoto, 2009; Wang et al., 2009b; Cooper et al., 2010; Wang et al., 2012; Lin et al., 2014, 2015; Zhang et al., 2014), such as $-0.56 \mathrm{ppbv} \mathrm{yr}^{-1}$ over Lin'an in eastern China (Xu et al., 2008), $+0.58 \mathrm{ppbv} \mathrm{yr}^{-1}$ over Hong Kong in southern China (Wang et al., 2009b), $+1.0 \mathrm{ppbv} \mathrm{yr}^{-1}$ at Mount Happo in Japan (for springtime $\mathrm{O}_{3}$; Tanimoto, 2009), and $+0.35 \mathrm{ppbv} \mathrm{yr}^{-1}$ over Hawaii in the North Pacific (for autumn $\mathrm{O}_{3}$; Lin et al., 2014). Asian $\mathrm{NO}_{x}$ emissions almost doubled over the past 20 years (Yang et al., 2015), which contributed to the increased $\mathrm{O}_{3}$ observed over the regions downwind of Asia (Lin et al., 2017).

Future changes in tropospheric $\mathrm{O}_{3}$ concentrations have also been predicted by modeling studies (Racherla and Adams, 2006, 2009; Lin et al., 2008; Wu et al., 2008a; Lam et al., 2011; Wild et al., 2012; Gao et al., 2013; Liu et al., 2013; Wang et al., 2013; Lee et al., 2015; Val Martin et al., 2015; Schnell et al., 2016; Zhu and Liao, 2016). Wang et al. (2013), using the NASA GISS GCM and GEOS-Chem model combination, reported that the summer surface-layer $\mathrm{O}_{3}$ levels averaged over China would increase by $11.9 \mathrm{ppbv}$ due to the combined changes in climate and emissions from 2000-2050 under the SRES A1B scenario.

Meteorological parameters, especially winds that are important for $\mathrm{O}_{3}$ outflow, also exhibit variations on different timescales (Chang et al., 2000; Ding et al., 2008b; Sun et al., 2009; Zhang and Guo, 2010; Hirahara et al., 2012). Large IAVs in the East Asian summer monsoon (EASM) have been reported in previous studies (Zhu et al., 2012; Yang et al., 2014). The decadal-scale weakening of the EASM since the 1950s has also been reported by many previous studies, and anomalous northeasterlies during the weak monsoon years were found over the western North Pacific near $40^{\circ} \mathrm{N}$, which 
did not favor the outflow of pollutants from northern China (Chang et al., 2000; Ding et al., 2008b; Zhu et al., 2012). On the basis of NCEP-NCAR reanalysis data, Sun et al. (2009) showed that the axis location of the East Asian subtropical westerly jet (EASWJ) had been displaced southward since the end of the 1970s, intensifying the westerly wind over $25-35^{\circ} \mathrm{N}$ and weakening it over $42-50^{\circ} \mathrm{N}$, therefore influencing the outflow of pollutants. Lin et al. (2014) reported that the interannual variability in springtime Asian $\mathrm{O}_{3}$ transport, as inferred by the East Asian COt (carbon monoxidelike tracer), was strongly influenced by ENSO-related shifts in the subtropical jet stream. They also reported that the decrease in ozone-rich Eurasian airflow reaching the eastern North Pacific in spring in the 2000s was attributed to more frequent La Niña events. Most of the models in the Coupled Model Intercomparison Project Phase 3 (CMIP3) predicted that the Asian jet would be intensified on its equatorward side by the end of the 21st century (Zhang and Guo, 2010; Hirahara et al., 2012).

Few previous studies have examined the IAVs, decadal trends, and future changes in $\mathrm{O}_{3}$ outflow. In this work, we examine the historical (1986-2006) and future (2000-2050) changes in the $\mathrm{O}_{3}$ outflow from East Asia and systematically quantify the roles of meteorological parameters and/or anthropogenic emissions in the changes. The descriptions of the model, emissions, and numerical simulations are presented in Sect. 2. Section 3 evaluates the model performance for tropospheric $\mathrm{O}_{3}$. Section 4 discusses the IAVs and the decadal trends in the $\mathrm{O}_{3}$ outflow from East Asia from 1986-2006. Future changes in $\mathrm{O}_{3}$ outflow from East Asia for 2000-2050 are presented in Sect. 5 .

\section{Methods}

\subsection{Model description}

We apply the global 3-D chemical transport model GEOS-Chem to simulate $\mathrm{O}_{3}$ outflow fluxes. The GEOSChem model includes a detailed simulation of $\mathrm{O}_{3}-\mathrm{NO}_{x}-$ hydrocarbon $(\sim 80$ species, $\sim 300$ chemical reactions; Bey et al., 2001) and aerosol chemistry. Aerosol species include sulfate $\left(\mathrm{SO}_{4}^{2-}\right)$, nitrate $\left(\mathrm{NO}_{3}^{-}\right)$, ammonium $\left(\mathrm{NH}_{4}^{+}\right.$; Park et al., 2004; Pye et al., 2009), black carbon (BC) and organic carbon (OC; Park et al., 2003), mineral dust (Fairlie et al., 2007), and sea salt (Alexander et al., 2005). The simulations account for the impacts of aerosols on the distributions and concentrations of $\mathrm{O}_{3}$ through heterogeneous reactions and changes in the photolysis rates (Lou et al., 2014).

To simulate historical changes in the Asian outflow of $\mathrm{O}_{3}$, the GEOS-Chem model is driven by the assimilated GEOS4 meteorological fields from the Goddard Earth Observing System (GEOS) of the NASA Global Modeling and Assimilation Office (GMAO). We perform simulations for 19862006, which are the years with available GEOS-4 meteoro- logical datasets. The version of the model used here has a horizontal resolution of $2^{\circ}$ latitude by $2.5^{\circ}$ longitude with 30 vertical layers.

To simulate future changes in $\mathrm{O}_{3}$ outflow fluxes from 2000-2050, the GEOS-Chem simulation is driven by meteorological data from the National Aeronautics and Space Administration Goddard Institute for Space Studies (NASA GISS) general circulation model (GCM) 3 (Rind et al., 2007) for both the "present day" (represented by data from 1996-2005) and the future (2046-2055), following Wu et al. (2008b), Pye et al. (2009), Wang et al. (2013), and Jiang et al. (2013). Both the GISS and GEOS-Chem models used here have a horizontal resolution of $4^{\circ}$ latitude by $5^{\circ}$ longitude with 23 vertical layers.

\subsection{Emissions}

For simulations from 1986-2006, the global anthropogenic emissions of reactive nitrogen oxides $\left(\mathrm{NO}_{x}\right)$, carbon monoxide $(\mathrm{CO})$, and sulfur dioxide $\left(\mathrm{SO}_{2}\right)$ in the model are from the Emission Database for Global Atmospheric Research (EDGAR) (Olivier and Berdowski, 2001). The global emissions of non-methane volatile organic compounds (NMVOCs) are from the Global Emissions Inventory Activity (GEIA) (Piccot et al., 1992). The global emissions of carbonaceous aerosols (BC and OC) follow Bond et al. (2007). Anthropogenic emissions of reactive $\mathrm{NO}_{x}, \mathrm{CO}$, $\mathrm{SO}_{2}, \mathrm{NH}_{3}$, and NMVOCs over East Asia are overwritten by the emissions inventory of Streets et al. (2003) and Zhang et al. (2009). The IAVs in anthropogenic emissions are represented by globally gridded annual scaling factors as described by van Donkelaar et al. (2008) for $\mathrm{NO}_{x}, \mathrm{CO}$, and NMVOCs. The biomass burning emissions are taken from the Global Fire Emissions Database (GFEDv3) (van der Werf et al., 2010) for 1997-2006. The biomass burning emission data before 1997 are unavailable due to the lack of datasets.

Figure 1 shows the evolution of anthropogenic and biomass burning emissions of $\mathrm{O}_{3}$ precursors $\left(\mathrm{NO}_{x}, \mathrm{CO}\right.$, NMVOCs) summed globally and for Asia $\left(60-150^{\circ} \mathrm{E}\right.$, $10^{\circ} \mathrm{S}-55^{\circ} \mathrm{N}$ ) from 1986-2006. The global anthropogenic emissions of these precursors exhibited no significant trends, while the Asian anthropogenic emissions showed large increases over the past 2 decades. Relative to 1986, the Asian anthropogenic emissions of $\mathrm{NO}_{x}, \mathrm{CO}$, and NMVOCs in 2006 had increased by $70.0,42.1$, and $50.9 \%$, respectively. Compared with anthropogenic emissions, biomass burning emissions had greater IAVs from 1997-2006. Figure 1 also shows the pathway for the global $\mathrm{CH}_{4}$ abundance used in our simulations of $\mathrm{O}_{3}$. The $\mathrm{CH}_{4}$ mixing ratio in 1986 was 1672 ppb, which had increased by $6.3 \%$ in 2006 . Note that from 1996-2006 when $\mathrm{NO}_{x}$ emissions and satellite $\mathrm{NO}_{2}$ columns were simultaneously available, the trend in $\mathrm{NO}_{x}$ emissions over East Central China (ECC; $\left.110-123^{\circ} \mathrm{E}, 30-40^{\circ} \mathrm{N}\right)$ was $+8.2 \% \mathrm{yr}^{-1}$ on the basis of the emission inventory used in this study; this is close to the trend of $+9.0 \% \mathrm{yr}^{-1}$ in $\mathrm{NO}_{2}$ 
Table 1. The anthropogenic emissions ${ }^{\mathrm{a}}$ of $\mathrm{O}_{3}$ precursors for the present day (the year 2000) and the future (the year 2050; under the SRES A1B scenario).

\begin{tabular}{lrrr|rrr}
\hline & \multicolumn{3}{c|}{ Global } & \multicolumn{3}{c}{ Asia $^{\mathrm{b}}$} \\
\cline { 2 - 7 } Species & 2000 & 2050 & Change (\%) & 2000 & 2050 & Change (\%) \\
\hline $\begin{array}{l}\mathrm{NO}_{x} \\
\left(\mathrm{Tg} \mathrm{N} \mathrm{yr}^{-1}\right)\end{array}$ & 33.4 & 59.6 & +78.4 & 10.9 & 28.3 & +159.6 \\
$\mathrm{CO}$ & 1054.2 & 1332.0 & +26.4 & 393.7 & 487.2 & +23.7 \\
$\left(\mathrm{Tg} \mathrm{CO} \mathrm{yr}^{-1}\right)$ & & & & & & \\
$\mathrm{NMVOCs}$ & 70.8 & 134.1 & +89.4 & 28.5 & 62.3 & +118.6 \\
$\left(\mathrm{Tg} \mathrm{C} \mathrm{yr}^{-1}\right)$ & 1750 & 2400 & +37.1 & 1750 & 2400 & +37.1 \\
$\begin{array}{l}\mathrm{CH}_{4} \\
(\mathrm{ppbv}\end{array}$ & & & & & & \\
\hline
\end{tabular}

${ }^{\mathrm{a}}$ Biomass burning emissions are included. ${ }^{\mathrm{b}}$ Asia covers the domain of $60-150^{\circ} \mathrm{E}, 10^{\circ} \mathrm{S}-55^{\circ} \mathrm{N}$.

columns averaged for ECC on the basis of tropospheric $\mathrm{NO}_{2}$ vertical column density (VCD) data retrieved from GOME (1996-2002) and SCIAMACHY (2003-2006), which are available from www.temis.nl.

For future simulations from 2000-2050, the anthropogenic emissions of $\mathrm{O}_{3}$ precursors, including $\mathrm{NO}_{x}, \mathrm{CO}$, and NMVOCs, are taken from Wu et al. (2008b). Those of $\mathrm{NH}_{3}$ and $\mathrm{SO}_{2}$ follow Pye et al. (2009). The future anthropogenic emissions of $\mathrm{O}_{3}$ precursors, aerosol precursors, and aerosols under the SRES A1B scenario are generated by the Integrated Model to Assess the Greenhouse Effect (IMAGE) socioeconomic model using growth factors for different species and countries (Streets et al., 2004). Table 1 shows the present-day (the year 2000) and the future (the year 2050) anthropogenic emissions of $\mathrm{O}_{3}$ precursors under the SRES A1B scenario. The global emissions of $\mathrm{NO}_{x}, \mathrm{CO}$, and NMVOCs are projected to increase by $78.4,26.4$, and $89.4 \%$ from 2000-2050; Asian emissions are projected to increase by $159.6,23.7$, and $118.6 \%$, respectively. Presentday methane mixing ratios are specified as $1750 \mathrm{ppbv}$ on the basis of observations (Wu et al., 2008b). The future methane concentrations are set to $2400 \mathrm{ppbv}$, following the SRES A1B scenario (Pye et al., 2009).

The natural emissions of $\mathrm{O}_{3}$ precursors, including $\mathrm{NO}_{x}$ from lighting and soil and NMVOCs from vegetation, are calculated on the basis of the assimilated GEOS-4 meteorological fields and the GISS CGM 3 meteorological parameters. The lightning $\mathrm{NO}_{x}$ emissions follow Price and Rind (1992) with the $\mathrm{NO}_{x}$ vertical profile proposed by Pickering et al. (1998). The soil $\mathrm{NO}_{x}$ emission scheme in the GEOS-Chem model is based on the work of Yienger and Levy (1995) and Wang et al. (1998). The biogenic emissions of NMVOCs are calculated according to the Model of Emissions of Gases and Aerosols from Nature (MEGAN; Guenther et al., 2006). Figure 2 shows the evolution of natural emissions summed globally and for Asia from 1986-2006. Both global and Asian $\mathrm{NO}_{x}$ emissions from lightning exhibited large IAVs and significant increasing trends. It has been shown that a warming climate leads to increased lightning $\mathrm{NO}_{x}$ (IPCC, 2013). Compared with lightning $\mathrm{NO}_{x}$ emissions, $\mathrm{NO}_{x}$ emissions from soil showed smaller IAVs and no significant decadal trend. Both global and Asian biogenic emissions of NMVOCs have been shown to have large IAVs as a result of the changes in both vegetation and meteorological parameters (Fu and Liao, 2012). For future simulations from 2000-2050, the natural emissions of $\mathrm{O}_{3}$ precursors are listed in Table 2. The simulated emissions of lightning $\mathrm{NO}_{x}$, soil $\mathrm{NO}_{x}$, and biogenic VOCs are projected to increase by $18.8,14.9$, and $22.1 \%$ globally and by $16.7,21.4$, and $18.9 \%$ for Asia, respectively.

The effects of changes in the stratosphere-troposphere exchange (STE) of $\mathrm{O}_{3}$ are not included in this study for past or future simulations. The cross-tropopause $\mathrm{O}_{3}$ flux is represented by the synthetic $\mathrm{O}_{3}$ (Synoz) method (McLinden et al., 2000), which imposes a global annual mean crosstropopause $\mathrm{O}_{3}$ flux of $500 \mathrm{Tg} \mathrm{yr}^{-1}$.

\section{Numerical experiments}

To examine the respective and combined impacts of meteorological parameters, anthropogenic emissions, and biomass burning emissions on the IAVs and decadal trends in $\mathrm{O}_{3}$ outflow from East Asia from 1986-2006, we perform simulations for four cases (Table 3):

a. Met: the simulation of $\mathrm{O}_{3}$ outflow for 1986-2006 to examine the effect of variations in meteorological parameters alone. The meteorological parameters vary from 1986 to 2006, and the anthropogenic emissions are fixed at 2006 levels. Biomass burning emissions are turned off.

b. Emis: the simulation of $\mathrm{O}_{3}$ outflow for 1986-2006 to examine the effect of variations in anthropogenic emissions alone. The anthropogenic emissions vary from 1986 to 2006, and the meteorological parameters are 
Table 2. Natural emissions of $\mathrm{O}_{3}$ precursors for the present day (the year 2000) and the future (the year 2050; under the SRES A1B scenario).

\begin{tabular}{|c|c|c|c|c|c|c|}
\hline \multirow[b]{2}{*}{ Species } & \multicolumn{3}{|c|}{ Global } & \multicolumn{3}{|c|}{ Asia* } \\
\hline & 2000 & 2050 & Change (\%) & 2000 & 2050 & Change (\%) \\
\hline $\begin{array}{l}\text { Lightning } \mathrm{NO}_{x} \\
\left(\operatorname{Tg}_{\mathrm{Ngr}}^{-1}\right)\end{array}$ & 4.8 & 5.7 & +18.8 & 1.2 & 1.4 & +16.7 \\
\hline $\begin{array}{l}\text { Soil } \mathrm{NO}_{x} \\
\left(\mathrm{TgN}_{\mathrm{yr}}{ }^{-1}\right)\end{array}$ & 6.7 & 7.7 & +14.9 & 1.4 & 1.7 & +21.4 \\
\hline 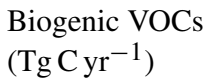 & 614.5 & 750.2 & +22.1 & 106.1 & 126.2 & +18.9 \\
\hline
\end{tabular}

* Asia covers the domain of $60-150^{\circ} \mathrm{E}, 10^{\circ} \mathrm{S}-55^{\circ} \mathrm{N}$.

Table 3. The experimental design of the simulations for 1986-2006.

\begin{tabular}{lcllll}
\hline Simulation & Simulated years & $\begin{array}{l}\text { Meteorological } \\
\text { parameters }\end{array}$ & $\begin{array}{l}\text { Anthropogenic } \\
\text { emissions }\end{array}$ & $\mathrm{CH}_{4}$ abundance & $\begin{array}{l}\text { Biomass burning } \\
\text { emissions }\end{array}$ \\
\hline Met & $1986-2006$ & $\begin{array}{l}\text { Vary from } \\
1986-2006\end{array}$ & Fixed at 2006 & Fixed at 2006 & Turned off \\
Emis & $1986-2006$ & Fixed at 2006 & $\begin{array}{l}\text { Vary from } \\
1986-2006\end{array}$ & $\begin{array}{l}\text { Vary from } \\
1986-2006\end{array}$ & Turned off \\
MetEmis & $1986-2006$ & $\begin{array}{l}\text { Vary from } \\
\text { 1986-2006 }\end{array}$ & $\begin{array}{l}\text { Vary from } \\
1986-2006\end{array}$ & $\begin{array}{l}\text { Vary from } \\
1986-2006\end{array}$ & Turned off \\
MetEmisB* & $1997-2006$ & $\begin{array}{l}\text { Vary from } \\
\text { Vary from }\end{array}$ & Vary from & Vary from \\
& & $1997-2006$ & $1997-2006$ & $1997-2006$ & $1997-2006$ \\
\hline
\end{tabular}

* The MetEmisB simulation is conducted for 1997-2006 owing to the unavailability of biomass burning emission data before 1997.

fixed at 2006 levels. Biomass burning emissions are turned off.

c. MetEmis: the simulation of $\mathrm{O}_{3}$ outflow for 1986-2006 with variations in both meteorological parameters and anthropogenic emissions from 1986-2006. Biomass burning emissions are turned off.

d. MetEmisB: the simulation of $\mathrm{O}_{3}$ outflow for 1997 2006 with variations in meteorological parameters, anthropogenic emissions, and biomass burning emissions from 1997-2006. Note that biomass burning emission data in the model are not available before 1997.

To identify the relative roles of future changes in meteorological parameters and emissions in 2000-2050 changes in the Asian $\mathrm{O}_{3}$ outflow flux, another four simulations are carried out: (a) Met2000Emis2000, present-day climate and emissions; (b) Met2050Emis2000, future climate and present-day anthropogenic emissions; (c) Met2000Emis2050, presentday climate and future anthropogenic emissions; and (d) Met2050Emis2050, future climate and emissions. Both the future climate and anthropogenic emissions follow the IPCC SRES A1B scenario.

The mass flux of $\mathrm{O}_{3}$ through the vertical plane along $135^{\circ} \mathrm{E}$ from 20 to $55^{\circ} \mathrm{N}$ from the surface to $100 \mathrm{hPa}$ is used to quantify the Asian $\mathrm{O}_{3}$ outflow. The metric of mass flux through a vertical plane was also used by Liu et al. (2002) to represent the Asian $\mathrm{O}_{3}$ outflow and by Jiang et al. (2013) and Yang et al. (2015) to represent the Asian aerosol outflow. It should be noted that the $\mathrm{O}_{3}$ outflow flux from East Asia includes the effects of emissions on different regions of the world owing to the relatively long lifetime ( $\sim 3$ weeks) of $\mathrm{O}_{3}$ (Fiore et al., 2002; Liao et al., 2006). However, Liu et al. (2002) found that anthropogenic sources in Asia made the largest contribution to the Asian outflow flux of $\mathrm{O}_{3}$.

\section{Model evaluation}

The GEOS-Chem simulations of $\mathrm{O}_{3}$ have been evaluated extensively for the US (Liu et al., 2006; Wu et al., 2008b; Zhang et al., 2008), Europe (Auvray and Bey, 2005; Liu et al., 2006; Kim et al., 2015), and China (Wang et al., 2013; Lou et al., 2014; Yang et al., 2014; Zhu and Liao, 2016). These studies showed that the GEOS-Chem model captured the magnitude and distribution of the surface-layer concentration and column burden of tropospheric $\mathrm{O}_{3}$ fairly well. The vertical distributions of $\mathrm{O}_{3}$ have also been evaluated by aircraft campaigns and ozonesonde measurements (Zhang et al., 2008; Walker et al., 2010; Wang et al., 2011), showing that the GEOS-Chem model closely reproduced the observed $\mathrm{O}_{3}$ profiles.

Here, we conduct comparisons with measurements to evaluate whether the version of the GEOS-Chem model used 
Table 4. Information for the sites with $\mathrm{O}_{3}$ measurements used in the model evaluation.

\begin{tabular}{lllrrr}
\hline Site & Location & Database & Height & $R^{\mathrm{a}}$ & $\mathrm{NMB}^{\mathrm{b}}(\%)$ \\
\hline Minami-Tori-shima & $24.3^{\circ} \mathrm{N}, 154.0^{\circ} \mathrm{E}$ & WDCGG & surface & 0.92 & +12.7 \\
Yonaguni-jima & $24.5^{\circ} \mathrm{N}, 123.0^{\circ} \mathrm{E}$ & WDCGG & surface & 0.93 & +12.6 \\
Rishiri Island & $45.1^{\circ} \mathrm{N}, 141.2^{\circ} \mathrm{E}$ & EANET & surface & 0.82 & +2.4 \\
Ogasawara & $27.1^{\circ} \mathrm{N}, 142.2^{\circ} \mathrm{E}$ & EANET & surface & 0.90 & +29.6 \\
Naha & $26.2^{\circ} \mathrm{N}, 127.7^{\circ} \mathrm{E}$ & WOUDC & $500-300 \mathrm{hPa}$ & 0.68 & -2.61 \\
& & & $700-500 \mathrm{hPa}$ & 0.77 & +16.4 \\
& & & $850-700 \mathrm{hPa}$ & 0.85 & +24.3 \\
& & & $1000-850 \mathrm{hPa}$ & 0.88 & +39.5 \\
& $36.1^{\circ} \mathrm{N}, 140.1^{\circ} \mathrm{E}$ & WOUDC & $500-300 \mathrm{hPa}$ & 0.55 & +15.8 \\
& & & $700-500 \mathrm{hPa}$ & 0.76 & +12.3 \\
& & & $850-700 \mathrm{hPa}$ & 0.76 & +8.61 \\
& & & $1000-850 \mathrm{hPa}$ & 0.60 & +8.5 \\
\hline
\end{tabular}

${ }^{\mathrm{a}}$ The correlation coefficient $(R)$ between the observed and simulated monthly $\mathrm{O}_{3}$ mixing ratios. ${ }^{\mathrm{b}}$ The normalized mean bias (NMB, \%) between the observed and simulated monthly $\mathrm{O}_{3}$ mixing ratios.

in this study can capture the temporal variations in tropospheric $\mathrm{O}_{3}$. We use the observations of tropospheric $\mathrm{O}_{3}$ available in East Asia as summarized in Table 4. Observations at two sites (Minami-Tori-shima and Yonaguni-jima) are from the World Data Centre for Greenhouse Gases (WDCGG; http://ds.data.jma.go.jp/gmd/wdcgg/), and those at another two sites (Rishiri Island and Ogasawara) are from the Acid Deposition Monitoring Network in East Asia (EANET, www.eanet.asia/product/index.html). These are used to evaluate the simulated surface-layer $\mathrm{O}_{3}$ concentrations. The four Japanese sites are "remote" sites in the downwind regions of China. Figure 3 compares the time series of monthly surfacelayer $\mathrm{O}_{3}$ mixing ratios simulated by MetEmisB with those measured by WDCGG and EANET. The simulated surfacelayer $\mathrm{O}_{3}$ levels agree well with observations at all four stations. The model captures the seasonal cycles and interannual variations of surface $\mathrm{O}_{3}$ fairly well with high correlation coefficients of 0.82-0.93 (Table 4). Generally, the GEOS-Chem model can capture the high values in early spring or winter when the Asian $\mathrm{O}_{3}$ outflow flux is the highest, but it overestimates the low values in summer when the Asian $\mathrm{O}_{3}$ outflow is at a minimum.

To evaluate the simulated $\mathrm{O}_{3}$ concentrations for the boundary layer and the middle and upper troposphere, we use the ozonesonde data at two Japanese sites from World Ozone and Ultraviolet Radiation Data Centre (WOUDC, http://www. woudc.org/). The information for the two sites (Naha and Tsukuba) is listed in Table 4. Figure 4 compares the time series of monthly $\mathrm{O}_{3}$ mixing ratios simulated by MetEmisB with those measured by ozonesonde. Comparisons are shown for four altitudes in the troposphere. The GEOS-Chem model captures the seasonal cycles and interannual variations of tropospheric $\mathrm{O}_{3}$ at all altitudes with correlation coefficients ranging from 0.68 to 0.88 for the Naha site and from 0.55 to 0.76 for the Tsukuba site. However, the agreement with ozonesonde in the lowermost layer $(1000-850 \mathrm{hPa})$ seems to be poorer than that with WDCGG or EANET. It is noted that the ground-based measurements (WDCGG or EANET) and simulation results are calculated from continuous data, while the ozonesondes are regularly launched at a fixed local time with a typical frequency of 1-2 weeks (Tanimoto et al., 2015). The inconsistency in sampling time may be responsible for the poorer agreement with ozonesonde.

The increasing trend in surface-layer $\mathrm{O}_{3}$ in East Asia over the past 2 decades was reported by previous studies (Ding et al., 2008a; Wang et al., 2009b; Xu et al., 2016). Figure 5 compares the simulated trends in seasonal or annual mean surface-layer $\mathrm{O}_{3}$ concentrations from the MetEmis experiment with the observed trends collected from previous studies. The simulated $\mathrm{O}_{3}$ concentrations exhibit statistically significant increasing trends at all sites except for Waliguan in winter, although the model underestimates the trends for some stations and seasons. The modeled $\mathrm{O}_{3}$ trends were also reported to have low biases in previous studies (Tanimoto et al., 2009; Parrish et al., 2014; Strode et al., 2015). Parrish et al. (2014) compared $\mathrm{O}_{3}$ trends simulated by three chemistryclimate models with observations at Asian sites and reported that one model captured less than one-third of the observed increasing trend, whereas the other two models suggested no significant increasing trends.

In general, the GEOS-Chem model can capture the seasonal cycles and interannual variations in tropospheric $\mathrm{O}_{3}$ fairly well, although the model overestimates the low values in summer, indicating an overestimation of the Asian $\mathrm{O}_{3}$ outflow in summer. The increasing trends in surface-layer $\mathrm{O}_{3}$ in China over the past 2 decades can also be captured by the GEOS-Chem model, although the modeled $\mathrm{O}_{3}$ trends have low biases. 
(a) Global
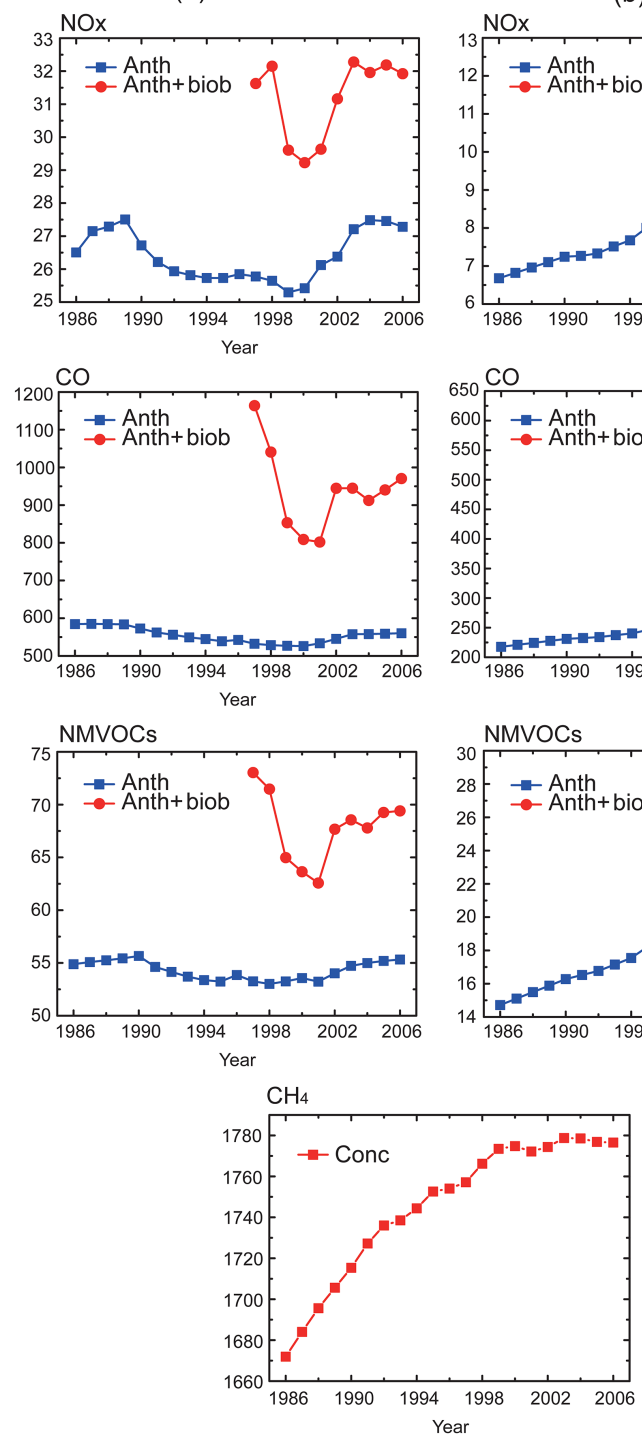

Figure 1. The evolution of annual anthropogenic and biomass burning emissions summed globally and for Asia $\left(60-150^{\circ} \mathrm{E}, 10^{\circ} \mathrm{S}-\right.$ $\left.55^{\circ} \mathrm{N}\right)$ for $\mathrm{NO}_{x}\left(\mathrm{Tg} \mathrm{Nyr}^{-1}\right), \mathrm{CO}\left(\mathrm{TgCO} \mathrm{yr}^{-1}\right)$, and NMVOCs $\left({\mathrm{TgC} \mathrm{yr}^{-1}}^{-}\right.$) from 1986-2006. The blue squares represent anthropogenic emissions, and the red circles represent the sum of anthropogenic emissions and biomass burning emissions. The last panel shows the evolution of global $\mathrm{CH}_{4}$ abundance (ppbv) from 19862006.

\section{Simulated Asian $\mathrm{O}_{3}$ outflow from 1986-2006}

\subsection{Seasonal patterns of Asian $\mathrm{O}_{3}$ outflow}

Figure 6 shows the pressure-latitude cross sections along $135^{\circ} \mathrm{E}$ of the seasonal $\mathrm{O}_{3}$ outflow fluxes averaged from 1997-2006 in the MetEmisB simulation. The maximum $\mathrm{O}_{3}$ fluxes were found in the middle to upper troposphere, which is consistent with Liu et al. (2002) and Wang et al. (2009a). This could be attributed to the vertical distribu- (a) Global

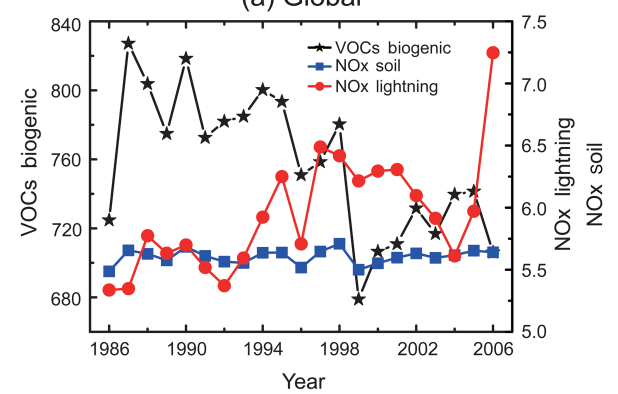

(b) Asia

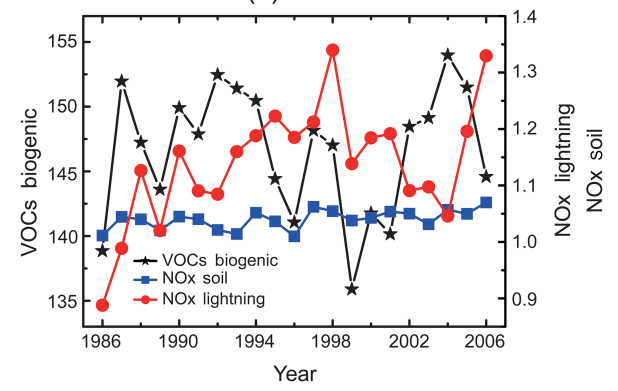

Figure 2. The evolution of annual natural emissions summed globally and for Asia $\left(60-150^{\circ} \mathrm{E}, 10^{\circ} \mathrm{S}-55^{\circ} \mathrm{N}\right)$ for lightning $\mathrm{NO}_{x}\left(\mathrm{Tg} \mathrm{Nyr}^{-1}\right)$, soil $\mathrm{NO}_{x}\left(\mathrm{Tg} \mathrm{Nyr}^{-1}\right)$, and biogenic VOCs ( $\mathrm{TgC} \mathrm{yr}^{-1}$ ) from 1986-2006.

tions of both zonal winds and $\mathrm{O}_{3}$ concentrations. The westerlies strengthen with altitude with the strongest winds occurring around $200 \mathrm{hPa}$ (known as the East Asian subtropical westerly jet; Ren et al., 2011). Concentrations of $\mathrm{O}_{3}$ are high in the upper troposphere over the mid-latitudes (Wang, 1999).

The seasonal mass fluxes through the meridional plane (along $135^{\circ} \mathrm{E}$ from 20 to $55^{\circ} \mathrm{N}$ and from the surface to $100 \mathrm{hPa}$ ) were calculated to be $509.6,437.6,126.6$, and 268.7 Tg season ${ }^{-1}$ for December-January-February (DJF), March-April-May (MAM), June-July-August (JJA), and September-October-November (SON), respectively. Although the seasonal flux was the highest in DJF, the monthly $\mathrm{O}_{3}$ flux through the panel peaked in March and reached the nadir in July (not shown in Fig. 6). Such monthly variations in the Asian $\mathrm{O}_{3}$ outflow flux agreed with those in Liu et al. (2002). The maximum $\mathrm{O}_{3}$ outflow in March was caused by the combined effects of meteorological conditions, biomass burning emissions, and stratospheric $\mathrm{O}_{3}$ intrusion. The "warm conveyor belt" (WCB) airstreams, which export pollution from the Asian boundary layer to the free troposphere, and the mid-latitude prevailing westerly winds in the free troposphere that transport pollution from Asia to the northwestern Pacific were strongest during the early spring period (Eckhardt et al., 2004; Pochanart et al., 2004). The contribution from Asian biomass burning emissions to the $\mathrm{O}_{3}$ outflow was at a maximum in the spring and insignifi- 

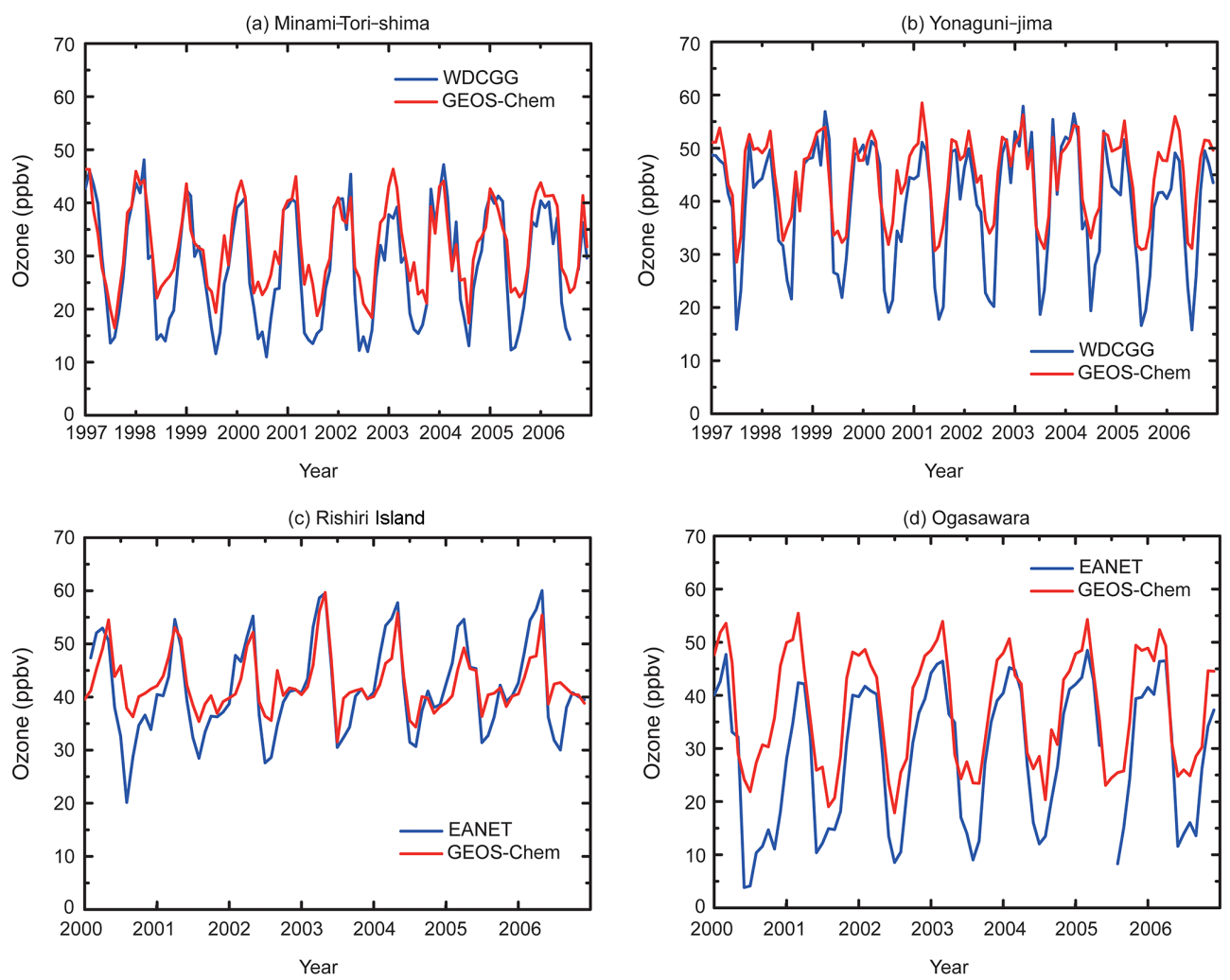

Figure 3. The time series of monthly surface-layer $\mathrm{O}_{3}$ mixing ratios measured by WDCGG and EANET (the blue line) and simulated by MetEmisB (the red line). (a) Minami-Tori-shima and (b) Yonaguni-jima are WDCGG sites, and (c) Rishiri Island and (d) Ogasawara are EANET sites.

cant in other seasons (Liu et al., 2002). The stratospheric $\mathrm{O}_{3}$ intrusion was also found to be the most effective in late winter and early spring (Danielsen and Mohnen, 1977; Mahlman and Moxim, 1978).

\subsection{IAVs and decadal trends in Asian $\mathrm{O}_{3}$ outflow}

Figure $7 \mathrm{a}$ shows the simulated annual $\mathrm{O}_{3}$ outflow fluxes through the meridional plane along $135^{\circ} \mathrm{E}$ from 20 to $55^{\circ} \mathrm{N}$ from the surface to $100 \mathrm{hPa}$ from $1986-2006$ in the Met, Emis, and MetEmis simulations. Figure $7 \mathrm{~b}$ shows the associated deviation from the mean (DEV). The simulations of the $\mathrm{O}_{3}$ outflow in Met, Emis, and MetEmis examined the effects of variations in the meteorological parameters alone, anthropogenic emissions alone, and both meteorological parameters and anthropogenic emissions, respectively. The outflow fluxes of $\mathrm{O}_{3}$ with changes in anthropogenic emissions alone (the Emis simulation) exhibited a statistically significant $(P<0.001)$ increasing trend. However, the magnitude of the increasing trend was very small; the decadal trend in the Asian $\mathrm{O}_{3}$ outflow flux in the Emis simulation was calculated to be $+16.7 \mathrm{Tg}_{\text {decade }}-1$ (i.e., $+1.2 \%$ decade $^{-1}$ ) using a linear fit with the least-squares method. The DEV, defined as

$\mathrm{DEV}=100 \% \times\left(C_{i}-\frac{1}{n} \sum_{i=1}^{n} C_{i}\right) /\left(\frac{1}{n} \sum_{i=1}^{n} C_{i}\right)$,

where $n$ is the number of years examined ( $n=21$ for 19862006) and $C_{i}$ is the simulated $\mathrm{O}_{3}$ outflow flux in year $i$, changed from $-1.3 \%$ (in 1986) to $+1.4 \%$ (in 2006), also indicating a small increasing trend in the $\mathrm{O}_{3}$ outflow flux. With variations in the meteorological parameters alone (the Met simulation), the simulated $\mathrm{O}_{3}$ outflow fluxes exhibited large IAVs but a statistically insignificant $(P>0.05)$ decadal trend of $-3.4 \%$ decade $^{-1}$. The DEV values in the Met simulation ranged from -8 to $+16.5 \%$. With variations in both anthropogenic emissions and meteorological parameters (the MetEmis simulation), the simulated $\mathrm{O}_{3}$ outflow showed large IAVs but a statistically insignificant $(P>0.05)$ decadal trend of $-2.2 \%$ decade $^{-1}$.

To analyze the IAVs in $\mathrm{O}_{3}$ outflow fluxes, the decadal trend obtained from the linear fit was removed from the time series of simulated $\mathrm{O}_{3}$ outflow fluxes, following the approach used in previous studies that examined the IAVs in aerosol outflow fluxes (Yang et al., 2015) and $\mathrm{O}_{3}$ concentrations (Camp et al., 2003). The deviations from the mean of the detrended $\mathrm{O}_{3}$ outflow fluxes from the Met, Emis, and MetEmis sim- 
(a) Naha
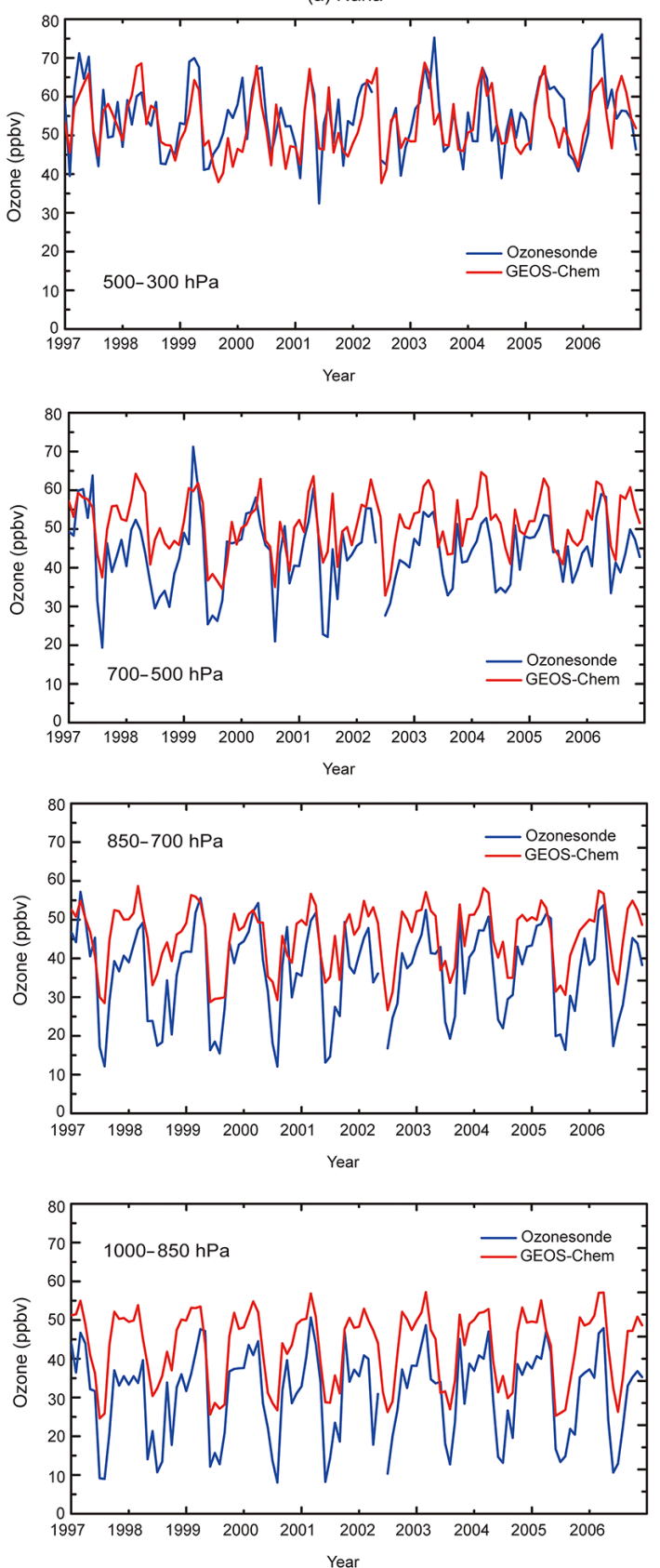
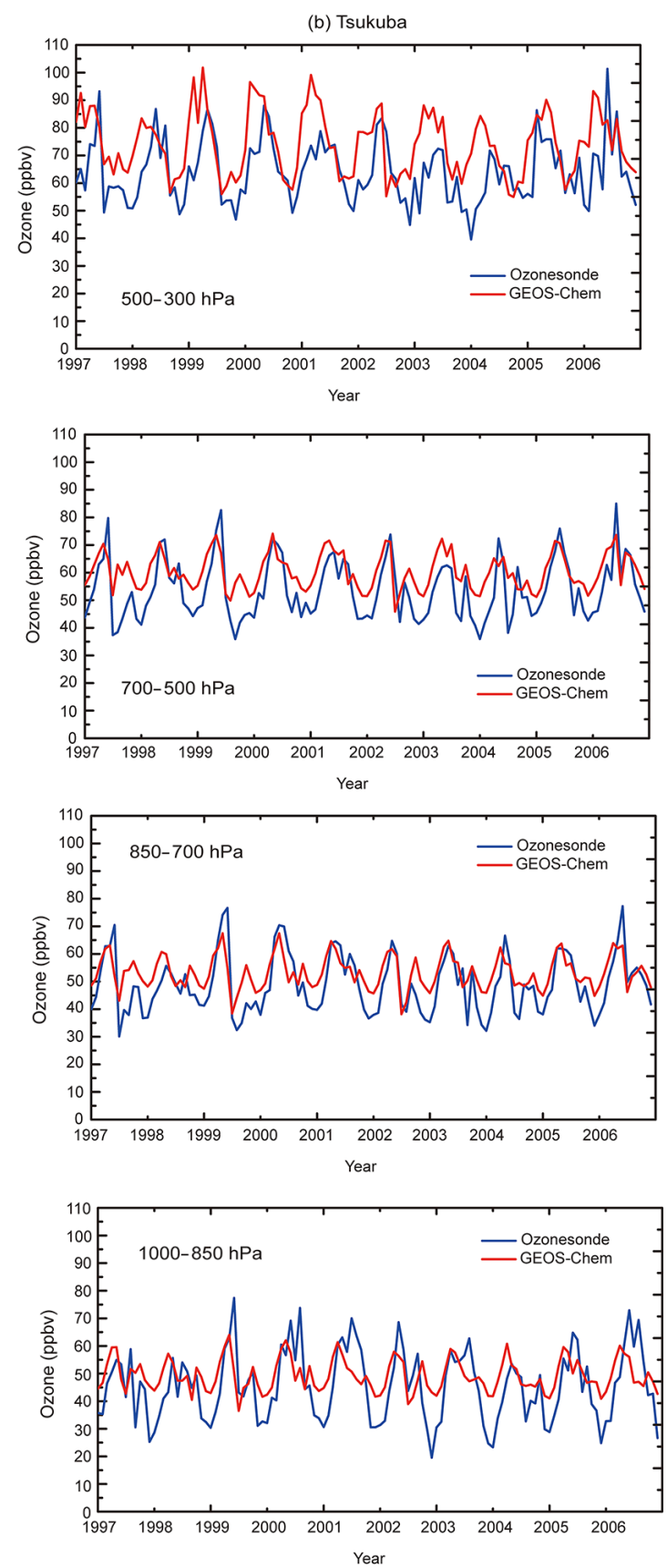

Figure 4. The time series of monthly $\mathrm{O}_{3}$ mixing ratios measured by ozonesonde (the blue line) and simulated by MetEmisB (the red line). (a) Naha and (b) Tsukuba are ozonesonde sites from the WOUDC. The comparisons are shown for four altitude levels in the troposphere.

ulations from 1986-2006 are shown in Fig. 7c. While the detrended outflow fluxes of $\mathrm{O}_{3}$ in the Met and MetEmis simulations showed large IAVs with DEV values in the range of -7.5 to $+13.5 \%$, the DEV values in the Emis simulation were very small (in the range of $\pm 0.3 \%$ ). The two deviation curves from the Met and MetEmis simulations almost coincided with each other, indicating the dominant role of variations in the meteorological parameters in the IAVs in the Asian $\mathrm{O}_{3}$ outflow flux.
The IAVs in the $\mathrm{O}_{3}$ outflow fluxes were further quantified with statistical variables of the mean absolute deviation (MAD) and the absolute percent departure from the mean (APDM), which have been used in previous IAV studies, such as Mu and Liao (2014), Lou et al. (2015), and Yang et al. (2015). The absolute IAVs in the $\mathrm{O}_{3}$ outflow fluxes can 


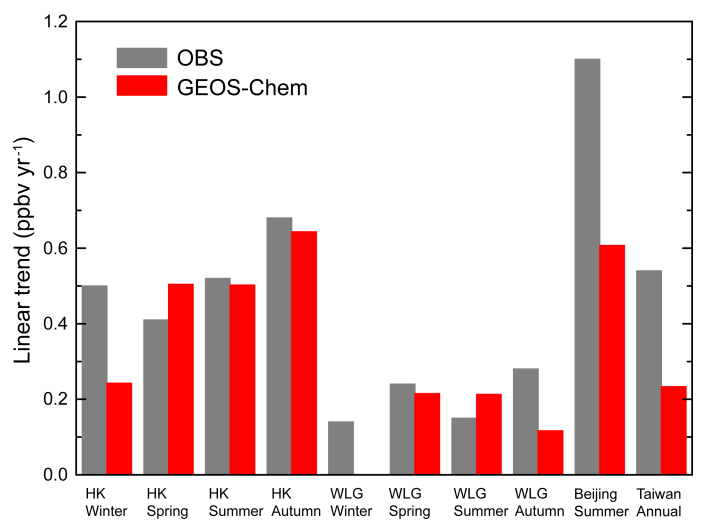

Figure 5. A comparison of the simulated trends in seasonal or annual mean surface-layer $\mathrm{O}_{3}$ concentrations from the MetEmis experiment with observations for Hong Kong $\left(22.2^{\circ} \mathrm{N}, 114.3^{\circ} \mathrm{E}\right.$; 1994-2007; Wang et al., 2009b), Waliguan $\left(36.3^{\circ} \mathrm{N}, 100.9^{\circ} \mathrm{E}\right.$; 1994-2013; Xu et al., 2016), Beijing $\left(40.0^{\circ} \mathrm{N}, 116.5^{\circ} \mathrm{E}\right.$; 20012006; Tang et al., 2009), and Taiwan $\left(23.5^{\circ} \mathrm{N}, 121.0^{\circ} \mathrm{E}\right.$; 1994 2007; Lin et al., 2010). The simulated trend at the Waliguan site for the winter is statistically insignificant. The trends in the seasonal mean $\mathrm{O}_{3}$ concentrations at the Taiwan station are unavailable. (a) DJF

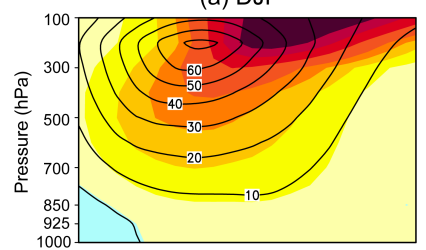

(c) JJA

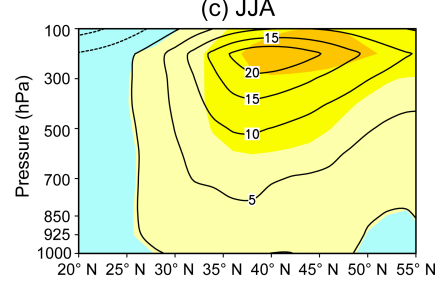

(b) MAM

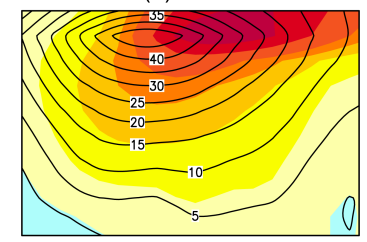

(d) SON

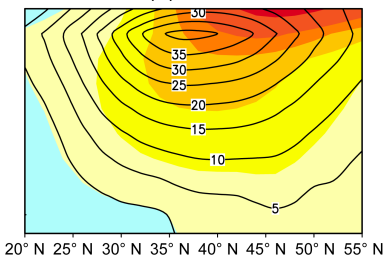

\begin{tabular}{llllllll}
\hline & 1 & 1 & $\mid$ & $\mid$ & 1 & 1 & 1 \\
0 & 5 & 10 & 15 & 20 & 30 & 40 & 50
\end{tabular}

Figure 6. The pressure-latitude cross sections along $135^{\circ} \mathrm{E}$ of the simulated seasonal $\mathrm{O}_{3}$ outflow fluxes and zonal winds in four seasons averaged from 1997-2006 in the MetEmisB simulation. The $\mathrm{O}_{3}$ mass fluxes are shown by the colored shading $\left(\mathrm{kg}\right.$ season ${ }^{-1} \mathrm{~m}^{-2}$ ), and the winds are represented by the contours $\left(\mathrm{m} \mathrm{s}^{-1}\right)$. The positive values represent eastward fluxes, and the negative values represent westward fluxes.

be quantified by the MAD, defined as

$\mathrm{MAD}=\frac{1}{n} \sum_{i=1}^{n}\left|C_{i}-\frac{1}{n} \sum_{i=1}^{n} C_{i}\right|$,

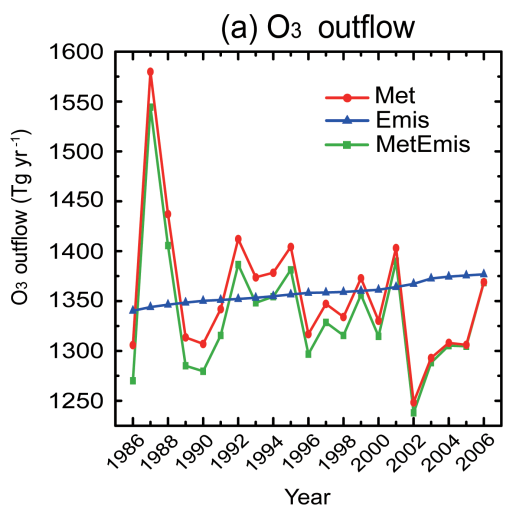

(b) Deviation

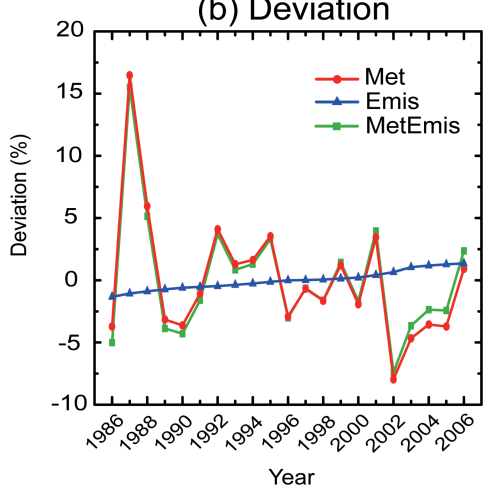

(c) Deviation detrended

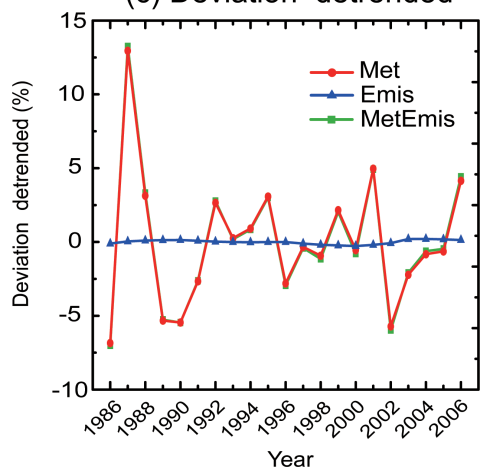

Figure 7. The evolution of the following: (a) the annual $\mathrm{O}_{3}$ outflow fluxes $\left(\mathrm{Tg} \mathrm{yr}^{-1}\right)$ across the meridional plane along $135^{\circ} \mathrm{E}$ from 20 to $55^{\circ} \mathrm{N}$ and from the surface to $100 \mathrm{hPa}$ from $1986-2006$ in the Met, Emis, and MetEmis simulations; (b) the associated deviations from the mean (\%); and (c) the deviations from the mean $(\%)$ of the detrended $\mathrm{O}_{3}$ outflow fluxes. The deviation from the mean (DEV) is defined in Sect. 4.2.

while the IAVs relative to the multiyear average outflow flux can be quantified by the APDM, defined as

$\mathrm{APDM}=100 \% \times \mathrm{MAD} /\left(\frac{1}{n} \sum_{i=1}^{n} C_{i}\right)$,

where $n$ is the number of years examined ( $n=21$ for years 1986-2006) and $C_{i}$ i s the detrended $\mathrm{O}_{3}$ outflow flux in year 
(a) MAD
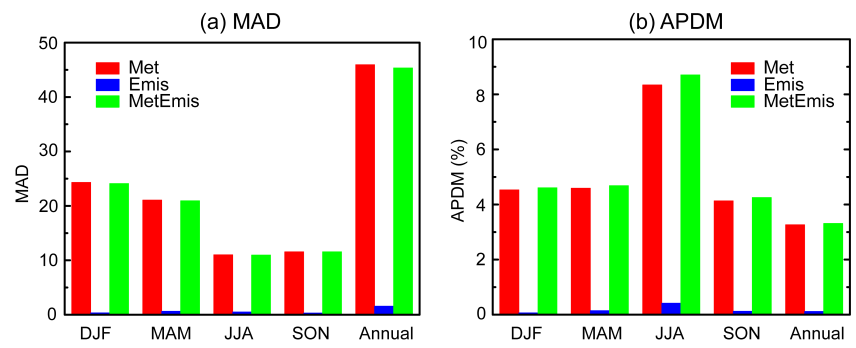

Figure 8. The MAD and APDM values of the detrended seasonal and annual $\mathrm{O}_{3}$ outflow fluxes across the meridional plane along $135^{\circ} \mathrm{E}$ from 20 to $55^{\circ} \mathrm{N}$ and from the surface to $100 \mathrm{hPa}$ from 1986-2006 in the Met, Emis, and MetEmis simulations. Both MAD and APDM are defined in Sect. 4.2. The units of MAD are $\mathrm{Tg}$ season ${ }^{-1}$ for seasonal fluxes and $\mathrm{Tg}_{\mathrm{yr}}-1$ for annual fluxes.

$i$. The MAD and APDM values of the detrended seasonal and annual $\mathrm{O}_{3}$ outflow fluxes across the meridional plane along $135^{\circ} \mathrm{E}$ from 20 to $55^{\circ} \mathrm{N}$ from the surface to $100 \mathrm{hPa}$ are shown in Fig. 8. The seasonal MAD and APDM values in the Emis simulation were close to zero, while those in the Met and MetEmis simulations were relatively large. The APDM values in the Met and MetEmis simulations were at a maximum in JJA and at a minimum in SON. The MAD and APDM values in the Met simulation were almost identical to those in the MetEmis simulation, which indicated again that the IAVs in the $\mathrm{O}_{3}$ outflow fluxes were mainly dependent on the variations in meteorological conditions, rather than the variations in anthropogenic emissions. With variations in both the meteorological parameters and anthropogenic emissions, the seasonal APDM values were in the range of 4-9\% and the annual APDM value was $3.3 \%$.

Figure 9 shows the pressure-latitude cross sections of the MAD values along $135^{\circ} \mathrm{E}$ for detrended annual $\mathrm{O}_{3}$ outflow fluxes from the Met, Emis, and MetEmis simulations. The $\mathrm{O}_{3}$ outflow in the Met simulation exhibited large IAVs throughout the whole troposphere with MAD values greater than $0.2 \mathrm{~kg} \mathrm{yr}^{-1} \mathrm{~m}^{-2}$. The MAD values increased with altitude, which could be attributed to the vertical distributions of the IAVs in the westerly winds (see the MAD values of the winds in Fig. 9a). The variations in anthropogenic emissions led to very small IAVs with MAD values less than $0.2 \mathrm{~kg} \mathrm{yr}^{-1} \mathrm{~m}^{-2}$ (Fig. 9b) throughout the troposphere. With variations in both the meteorological parameters and anthropogenic emissions, the MAD values (Fig. 9c) showed almost identical magnitudes and spatial distributions to those in the Met simulation (Fig. 9a), indicating the dominant role of variations in meteorological conditions in the IAVs in the $\mathrm{O}_{3}$ outflow.

Variations in meteorological conditions can influence the IAVs in the $\mathrm{O}_{3}$ outflow fluxes by changing the $\mathrm{O}_{3}$ concentrations over East Asia (Yang et al., 2014; Lou et al., 2015) and by altering the zonal winds (Kurokawa et al., 2009). The $\mathrm{O}_{3}$ outflow flux is simulated to correlate positively with the zonal winds averaged over $20-55^{\circ} \mathrm{N}$ along $135^{\circ} \mathrm{E}$ with a (a) Met

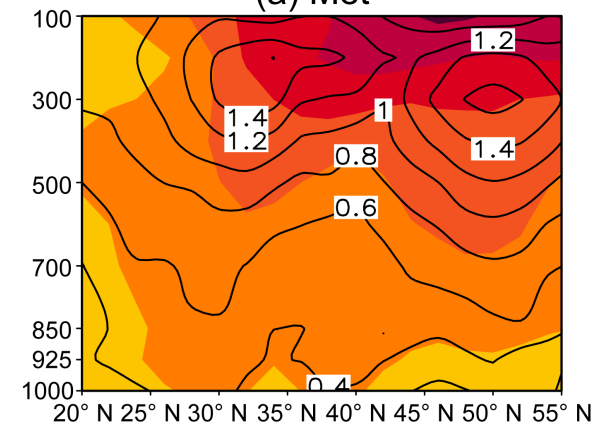

(b) Emis

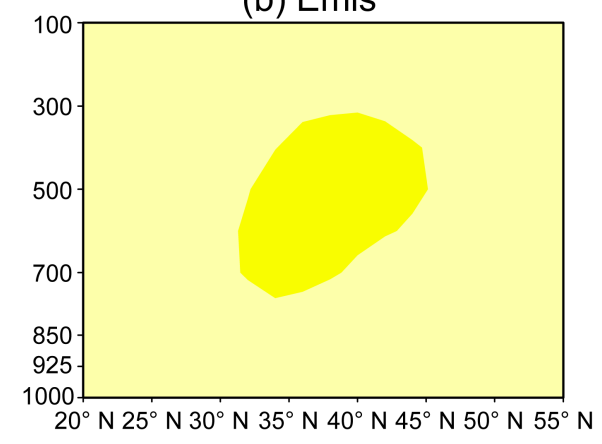

(c) MetEmis

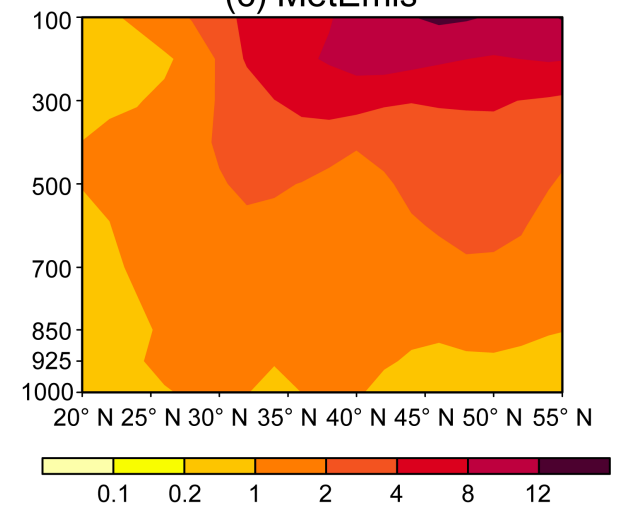

Figure 9. The pressure-latitude cross sections along $135^{\circ} \mathrm{E}$ of the MAD values for the detrended annual $\mathrm{O}_{3}$ outflow fluxes and zonal winds from 1986-2006 in the Met, Emis, and MetEmis simulations. The MAD values for $\mathrm{O}_{3}$ mass fluxes are shown by the colored shading $\left(\mathrm{kg} \mathrm{yr}^{-1} \mathrm{~m}^{-2}\right)$, and the MAD values for the winds are represented by the contours $\left(\mathrm{m} \mathrm{s}^{-1}\right)$.

high correlation coefficient of +0.71 for annual fluxes and zonal winds. The correlation coefficient between $\mathrm{O}_{3}$ fluxes and zonal winds is calculated to be +0.96 in summer when the APDM values of $\mathrm{O}_{3}$ outflow fluxes are at a maximum. The high correlation coefficients indicate that the variation in zonal winds is the key factor that leads to the large IAVs in $\mathrm{O}_{3}$ outflow fluxes. 
Table 5. Simulated present-day $\mathrm{O}_{3}$ fluxes and projected changes from the present day (1996-2005) to the future (2046-2055) through the vertical plane along $135^{\circ} \mathrm{E}$ from 20 to $55^{\circ} \mathrm{N}$ and from the surface to $100 \mathrm{hPa}$ due to future climate change alone, changes in anthropogenic emissions alone, and changes in both climate and emissions.

\begin{tabular}{lrrrr}
\hline \multicolumn{4}{c}{$\mathrm{O}_{3}$ fluxes* } \\
\cline { 2 - 5 } & $\begin{array}{r}\text { Met2000Emis2000 } \\
\text { (present day) }\end{array}$ & $\begin{array}{r}\text { Met2050Emis2000 } \\
\text { (climate) }\end{array}$ & $\begin{array}{r}\text { Met2000Emis2050 } \\
\text { (emissions) }\end{array}$ & $\begin{array}{r}\text { Met2050Emis2050 } \\
\text { (climate + emissions) }\end{array}$ \\
\hline DJF & 792.9 & $778.3(-1.8 \%)$ & $850.5(+7.3 \%)$ & $853.7(+7.7 \%)$ \\
MAM & 597.0 & $640.4(+7.3 \%)$ & $639.0(+7.0 \%)$ & $698.0(+16.9 \%)$ \\
JJA & 146.5 & $167.7(+14.5 \%)$ & $161.3(+10.1 \%)$ & $187.2(+27.8 \%)$ \\
SON & 340.7 & $327.8(-3.8 \%)$ & $374.1(+9.8 \%)$ & $368.1(+8.0 \%)$ \\
Annual & 1877.1 & $1914.1(+2.0 \%)$ & $2024.9(+7.9 \%)$ & $2106.9(+12.2 \%)$ \\
\hline
\end{tabular}

* The units are $\mathrm{Tg}_{\mathrm{g}}$ eason ${ }^{-1}$ for seasonal fluxes and $\mathrm{Tg} \mathrm{yr}^{-1}$ for annual fluxes. The values in parentheses are percentage changes relative to the present-day fluxes.

\subsection{Effect of variations in biomass burning emissions}

The biomass burning emissions of the $\mathrm{O}_{3}$ precursors exhibited large IAVs from 1997-2006 (Fig. 1). To analyze the impacts of biomass burning emissions on the IAVs in $\mathrm{O}_{3}$ outflow fluxes, we compare the MAD and APDM values of detrended $\mathrm{O}_{3}$ outflow fluxes from 1997-2006 in the MetEmis and MetEmisB simulations. The MAD (APDM) was calculated to be $31.17 \mathrm{Tg} \mathrm{yr}^{-1}(2.35 \%)$ in the MetEmis simulation and $31.82 \mathrm{Tg} \mathrm{yr}^{-1}(2.36 \%)$ in the MetEmisB simulation. The minor influence of biomass burning emissions on the IAVs in the $\mathrm{O}_{3}$ outflow fluxes from East Asia was also supported by Voulgarakis et al. (2015). Furthermore, Lin et al. (2014) reported that meteorological variability, compared with the variability in biomass burning, was much more important for driving the IAVs in springtime $\mathrm{O}_{3}$ at the Mauna Loa Observatory, a remote North Pacific site sensitive to Asian pollution outflow.

\section{Future changes in Asian $\mathrm{O}_{3}$ outflow for 2000-2050}

In this part of the study, we quantify the future decadal changes in the Asian $\mathrm{O}_{3}$ outflow from 2000-2050 under the SRES A1B scenario and examine the relative impacts of variations in climate and anthropogenic emissions on the changes. We conduct each simulation for 10 years driven by 1996-2005 meteorology to represent the present-day (the year 2000) climate and by 2046-2055 meteorological fields to represent the future (the year 2050) climate, following 1 year of model spin-up. All the results presented below are 10-year averages. The simulated present-day and future changes in seasonal and annual fluxes in $\mathrm{O}_{3}$ across the vertical plane along $135^{\circ} \mathrm{E}$ from 20 to $55^{\circ} \mathrm{N}$ are summarized in Table 5.

\subsection{Present-day $\mathrm{O}_{3}$ outflow}

The pressure-latitude cross sections along $135^{\circ} \mathrm{E}$ of the simulated present-day (Met2000Emis2000) seasonal $\mathrm{O}_{3}$ outflow fluxes, driven by the meteorological inputs provided by GISS GCM 3, are shown in Fig. 10a. The magnitudes, spatial distributions, and seasonal variations agree closely with those driven by the assimilated GEOS-4 meteorological fields (Fig. 6). The $\mathrm{O}_{3}$ outflow flux through the vertical plane is simulated to be $1877.1 \mathrm{Tg} \mathrm{yr}^{-1}$ with GISS GCM 3 meteorology and $1342.5 \mathrm{Tg} \mathrm{yr}^{-1}$ with the GEOS-4 assimilated meteorological fields, which indicates the reliability of the simulated present-day $\mathrm{O}_{3}$ outflow fluxes.

\subsection{Effect of future climate change}

Relative to the present-day value, the 2050 annual outflow of $\mathrm{O}_{3}$ is estimated to increase by $2.0 \%$ (Table 5) as a result of climate change alone (Met2050Emis2000 minus Met2000Emis2000). The outflow of $\mathrm{O}_{3}$ shows a slight decrease of 1.8 in DJF and of $3.8 \%$ in SON, but a large increase of 14.5 in JJA and of $7.3 \%$ in MAM. The spatial distributions of the projected changes in $\mathrm{O}_{3}$ fluxes are consistent with those of the changes in zonal winds (Fig. 10b). The wind speed of the westerlies in DJF and SON decreases across the troposphere over $30-45^{\circ} \mathrm{N}$, leading to reductions in the $\mathrm{O}_{3}$ outflow fluxes. In contrast, increases in the zonal winds in JJA and MAM lead to increases in $\mathrm{O}_{3}$ outflow fluxes throughout the troposphere over $30-45^{\circ} \mathrm{N}$. Our projected future changes in the zonal winds are consistent with previous studies. By analyzing 18 CMIP5 models, Huang and Wang (2016) assessed the future changes in atmospheric circulation in spring over East Asia. They found that although different models projected different changes (even in sign) in the zonal winds, the ensemble mean of 5 better-skill models among the 18 CMIP5 models exhibited overall increases in the zonal winds throughout the whole troposphere in spring, which agrees with our simulation. Based on 31 (29)-model ensemble mean results, Jiang and Tian (2013) showed that 
the westerlies along $135^{\circ} \mathrm{E}$ in winter (summer) were projected to weaken (strengthen). Such projected patterns of future changes in the westerlies in winter and summer are also captured by our model. The changes in $\mathrm{O}_{3}$ concentrations also contribute to the changes in $\mathrm{O}_{3}$ outflow; although the zonal winds are projected to increase north of $40^{\circ} \mathrm{N}$ in the upper troposphere in $\mathrm{SON}$, the $\mathrm{O}_{3}$ outflow fluxes are simulated to decrease because of the significant decreases in $\mathrm{O}_{3}$ levels north of $40^{\circ} \mathrm{N}$ in the upper troposphere (Fig. S1 in the Supplement).

\subsection{Effect of future changes in anthropogenic emissions}

The annual outflow of $\mathrm{O}_{3}$ through the vertical plane is simulated to increase by $7.9 \%$ relative to the present-day value (Table 5) as a result of the changes in anthropogenic emissions alone (Met2000Emis2050 minus Met2000Emis2000). Considering that the $\mathrm{O}_{3}$ outflow with changes in anthropogenic emissions alone exhibits an increasing trend of $1.2 \%$ decade $^{-1}$ from 1986-2006 (Sect. 4.2), the increasing trend of $1.2 \%$ decade $^{-1}$ (i.e., $6.0 \%$ half-century $^{-1}$ ) is close to the value of $7.9 \%$ for the future half-century.

The projected future $\mathrm{O}_{3}$ fluxes show increases in all seasons, which can be attributed to the increases in the $\mathrm{O}_{3}$ concentrations at all altitudes over Asia and upwind regions (i.e., Europe and Central Asia; Fig. S1) as a result of the increases in the anthropogenic emissions of the $\mathrm{O}_{3}$ precursors $\left(\mathrm{NO}_{x}\right.$ and NMVOCs) and $\mathrm{CH}_{4}$ concentrations. $\mathrm{NO}_{x}$ emissions in 2050 are projected to increase by $159.6 \%$ over Asia and by $78.4 \%$ globally, while NMVOCs emissions are projected to increase by $118.6 \%$ over Asia and by $89.4 \%$ globally under the SRES A1B scenario (Table 1). The $\mathrm{CH}_{4}$ mixing ratios are projected to increase by $37.1 \%$ relative to the presentday value. The largest increases in $\mathrm{O}_{3}$ outflow fluxes are located in the middle to upper troposphere (Fig. 10c) owing to the strong westerlies located here. It is noted that, in spite of the significant increases in emissions, the simulated surfacelayer $\mathrm{O}_{3}$ concentrations show slight decreases over the North China Plain in DJF, which subsequently leads to small decreases in the $\mathrm{O}_{3}$ outflow fluxes at the surface layer over $30-40^{\circ} \mathrm{N}$. In DJF, biogenic VOC emissions are especially low over the North China Plain, whereas anthropogenic $\mathrm{NO}_{x}$ emissions are fairly high due to residential heating, leading to a low VOCs / $\mathrm{NO}_{x}$ ratio in this region (Lou et al., 2010; Fu et al., 2012). Therefore, increases in $\mathrm{NO}_{x}$ emissions lead to decreases in surface-layer $\mathrm{O}_{3}$ concentrations over the North China Plain.

\subsection{Effect of future changes in both climate and anthropogenic emissions}

The annual outflow of $\mathrm{O}_{3}$ through the vertical plane is projected to increase by $12.2 \%$ (Table 5) from 20002050 as a consequence of future changes in both climate and anthropogenic emissions (Met2050Emis2050 mi- nus Met2000Emis2000). Climate change in DJF and SON slightly offsets the effects of changes in the anthropogenic emissions, while climate change in MAM and JJA enhances the effects of variations in anthropogenic emissions. When considering future changes in both emissions and climate, the projected $\mathrm{O}_{3}$ outflow fluxes show increases throughout almost the entire troposphere along $135^{\circ} \mathrm{E}$ in all seasons (Fig. 10d).

\section{Uncertainty discussion}

There are some uncertainties in our simulations. First, the influence of the interannual variation in the stratospheretroposphere exchange on tropospheric $\mathrm{O}_{3}$ is not considered in this study. Terao et al. (2008) reported that the stratosphere-troposphere exchange had large impacts on the interannual variability in tropospheric $\mathrm{O}_{3}$ over Canada and Europe, but the impact was much smaller over East Asia. The second is the uncertainty associated with the selection of the longitudinal transect. We calculate the $\mathrm{O}_{3}$ flux through the vertical plane along $135^{\circ} \mathrm{E}$ because $135^{\circ} \mathrm{E}$ is the easternmost boundary of China (i.e., the Wusuli River in northeastern China). We also calculate the $\mathrm{O}_{3}$ outflow flux along $120^{\circ} \mathrm{E}$, which is closer to the ozone production region in central to eastern China, and find that the variations in $\mathrm{O}_{3}$ fluxes calculated at $120^{\circ} \mathrm{E}$ are similar to those calculated at $135^{\circ} \mathrm{E}$. With variations in both anthropogenic emissions and meteorological parameters (the MetEmis simulation), the simulated $\mathrm{O}_{3}$ outflow shows large IAVs but a statistically insignificant $(P>0.05)$ trend. The conclusion is consistent with that drawn from the variations in $\mathrm{O}_{3}$ outflow calculated at $135^{\circ} \mathrm{E}$. Finally, projecting the future atmospheric circulation on regional scales has a large amount of uncertainty, which is undergoing continuous improvement.

\section{Conclusions}

We quantify the past and future changes in the $\mathrm{O}_{3}$ outflow from East Asia using the global 3-D chemical transport model GEOS-Chem. The historical (1986-2006) simulations are driven by the assimilated GEOS-4 meteorological fields, and the future (2000-2050) simulations under the IPCC SRES A1B scenario are driven by the meteorological fields archived from GISS GCM 3. Sensitivity studies are conducted to examine the respective impacts of meteorological parameters and emissions on the variations in the outflow flux.

The measurements from WDCGG and EANET are used to evaluate the simulated surface-layer $\mathrm{O}_{3}$ concentrations; the ozonesonde data from WOUDC are used to evaluate the simulated $\mathrm{O}_{3}$ concentrations for the boundary layer and the middle and upper troposphere. Generally, the seasonal cycles and interannual variations in tropospheric $\mathrm{O}_{3}$ concentrations are captured fairly well by the GEOS-Chem model with high 
(a) Present day
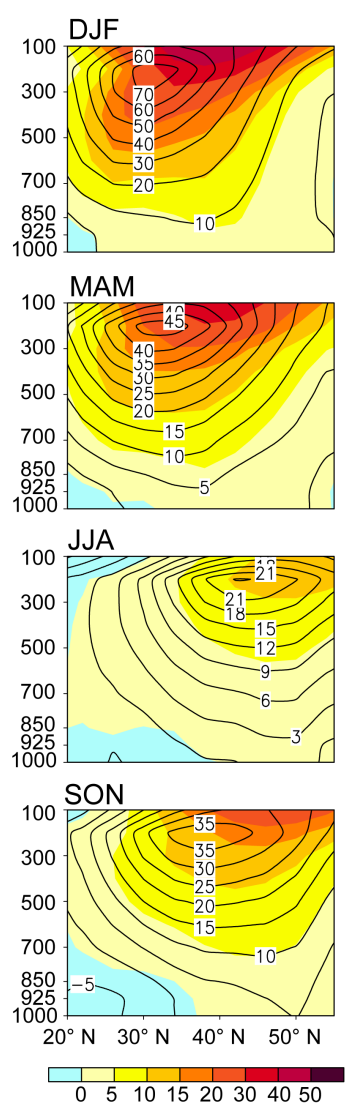

(b) Climate
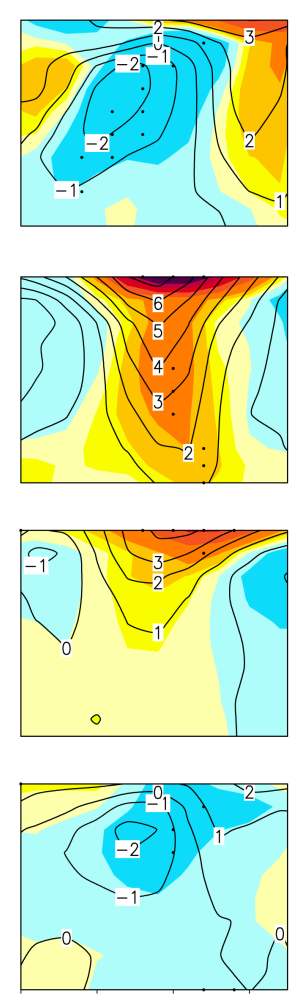

$20^{\circ} \mathrm{N} 30^{\circ} \mathrm{N} \quad 40^{\circ} \mathrm{N} 50^{\circ} \mathrm{N}$ (c) Emissions
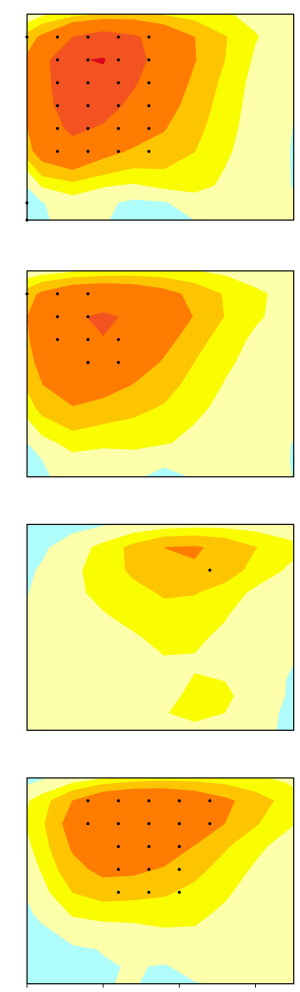

$20^{\circ} \mathrm{N} 30^{\circ} \mathrm{N} 40^{\circ} \mathrm{N} 50^{\circ} \mathrm{N}$ (d) Climate + emissions
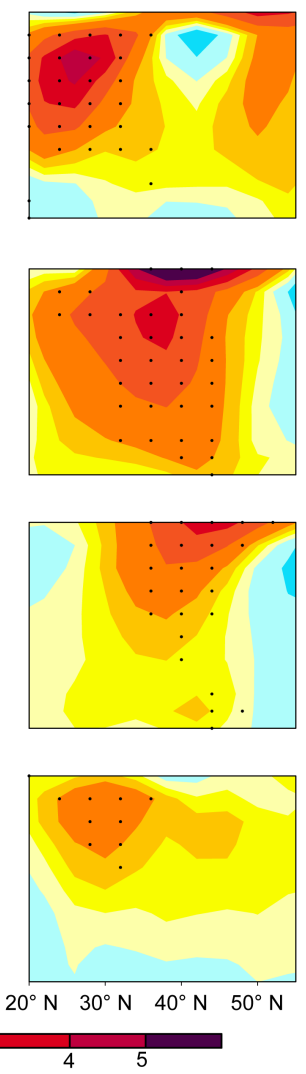

Figure 10. (a) The pressure-latitude cross sections along $135^{\circ} \mathrm{E}$ of the simulated present-day $\mathrm{O}_{3}$ mass fluxes and zonal winds (Met2000Emis2000). The projected changes in $\mathrm{O}_{3}$ mass fluxes and zonal winds from the present day (1996-2005) to the future (20462055) caused by (b) climate change alone (Met2050Emis2000 minus Met2000Emis2000), (c) changes in anthropogenic emissions alone (Met2000Emis2050 minus Met2000Emis2000), and (d) changes in both climate and anthropogenic emissions (Met2050Emis2050 minus Met2000Emis2000). The $\mathrm{O}_{3}$ mass fluxes are shown by the colored shading $\left(\mathrm{kg}\right.$ season $\left.{ }^{-1} \mathrm{~m}^{-2}\right)$, and the winds are represented by the contours $\left(\mathrm{m} \mathrm{s}^{-1}\right)$. The dotted areas are statistically significant at the $95 \%$ level, as determined by a two-sample Student's $t$ test.

correlation coefficients of $0.82-0.93$ at four ground-based sites and $0.55-0.88$ at two ozonesonde sites. The increasing trends in surface-layer $\mathrm{O}_{3}$ concentrations in East Asia over the past 2 decades can also be captured by the GEOS-Chem model, although the modeled $\mathrm{O}_{3}$ trends have low biases. The simulated Asian $\mathrm{O}_{3}$ outflow flux peaks in early spring and reaches the nadir in summer. The maximum $\mathrm{O}_{3}$ fluxes are located in the middle to upper troposphere.

The IAVs and decadal trends in Asian $\mathrm{O}_{3}$ outflow are examined from 1986-2006. The simulated $\mathrm{O}_{3}$ outflow fluxes showed large IAVs but an insignificant decadal trend; with variations in both meteorological parameters and anthropogenic emissions, the seasonal APDM values were in the range of 4-9\%. The sensitivity simulations showed that the large IAVs of the $\mathrm{O}_{3}$ outflow fluxes were mainly caused by the variations in meteorological conditions, rather than the variations in anthropogenic and biomass burning emissions. Although variations in the meteorological parameters could influence the IAVs in the $\mathrm{O}_{3}$ outflow fluxes by changing the
$\mathrm{O}_{3}$ concentrations over East Asia and by altering the zonal winds, the latter was identified to be the key factor because of the high correlation coefficient of +0.71 between the annual fluxes and the zonal winds.

The decadal changes in the Asian $\mathrm{O}_{3}$ outflow are also examined from 2000-2050. The present-day annual $\mathrm{O}_{3}$ flux through the vertical plane is calculated as $1877.1 \mathrm{Tg}$, which is projected to change from $2000-2050$ by $+2.0,+7.9$, and $+12.2 \%$ due to climate change alone, emissions change alone, and changes in both climate and emissions, respectively. In MAM and JJA, climate change plays a larger role in the future changes in $\mathrm{O}_{3}$ outflow compared with emissions changes, owing to the significant increases in the zonal winds in these two seasons. It is noted that climate change will aggravate the impacts of increases in anthropogenic emissions on the $\mathrm{O}_{3}$ outflow from East Asia from 2000-2050 under the SRES A1B scenario.

These findings are helpful for understanding the temporal evolution in the tropospheric $\mathrm{O}_{3}$ on different timescales in the 
downwind regions of East Asia. The observed IAVs in tropospheric $\mathrm{O}_{3}$ on a relatively short timescale can be attributed to variations in the meteorological parameters. Furthermore, the conclusions from this study will have important implications for long-term air quality planning for the regions downwind of China, such as Japan and the US. Since future climate change will increase the $\mathrm{O}_{3}$ outflow from East Asia, extra efforts are needed to reduce the anthropogenic emissions of $\mathrm{O}_{3}$ precursors to offset the adverse effects caused by climate change.

Data availability. GEOS-Chem is an open-access model developed collaboratively at Harvard University and other institutes in North America, Europe, and Asia. The source codes can be downloaded from http://acmg.seas.harvard.edu/geos/. The tropospheric $\mathrm{NO}_{2}$ vertical column density (VCD) data are retrieved from GOME (1996-2002) and SCIAMACHY (2003-2006), which are available from www.temis.nl. The $\mathrm{O}_{3}$ measurements at Minami-Torishima and Yonaguni-jima are available from the World Data Centre for Greenhouse Gases (WDCGG; http://ds.data.jma.go.jp/gmd/ wdcgg/). Those at Rishiri Island and Ogasawara are available from the Acid Deposition Monitoring Network in East Asia (EANET; www.eanet.asia/product/index.html). The ozonesonde data at Naha and Tsukuba are available from the World Ozone and Ultraviolet Radiation Data Centre (WOUDC; www.woudc.org). All data presented in this study are available upon request from the corresponding author.

\section{The Supplement related to this article is available online at doi:10.5194/acp-17-3729-2017-supplement.}

Author contributions. Hong Liao and Jia Zhu conceived the study and designed the experiments. Jia Zhu performed the simulations, carried out the data analysis, and prepared the paper. Yuhao Mao provided useful comments on the paper. Yang Yang and Hui Jiang helped with performing the experiments.

Competing interests. The authors declare that they have no conflict of interest.

Acknowledgements. This work was supported by the National Basic Research Program of China (973 Program, grant no. 2014CB441202) and the National Natural Science Foundation of China under grants 91544219 and 41475137. We acknowledge the free use of GOME and SCIAMACHY tropospheric $\mathrm{NO}_{2}$ vertical column density (VCD); data available from www.temis.nl. The following data centers are also acknowledged: the World Data Centre for Greenhouse Gases (WDCGG; http://ds.data.jma.go.jp/gmd/wdcgg/) operated by the Japan Meteorological Agency (JMA) in cooperation with the World Meteorological Organization (WMO); the World Ozone and Ultraviolet Radiation Data Centre (WOUDC; www.woudc.org) operated by Environment Canada for the Global Atmosphere Watch
(GAW) program of the WMO. The Rishiri Island and Ogasawara sites are operated by the Ministry of the Environment of Japan as part of the Acid Deposition Monitoring Network in East Asia (EANET; www.eanet.asia/product/index.html). We are also very grateful to the reviewers for their helpful comments and thoughtful suggestions.

Edited by: Y. Kanaya

Reviewed by: two anonymous referees

\section{References}

Alexander, B., Park, R. J., Jacob, D. J., Li, Q. B., Yantosca, R. M., Savarino, J., Lee, C. C. W., and Thiemens, M. H.: Sulfate formation in sea-salt aerosols: constraints from oxygen isotopes, J. Geophys. Res., 110, D10307, doi:10.1029/2004JD005659, 2005.

Ambrose, J. L., Reidmiller, D. R., and Jaffe, D. A.: Causes of high $\mathrm{O}_{3}$ in the lower free troposphere over the Pacific Northwest as observed at the Mt. Bachelor Observatory, Atmos. Environ., 45, 5302-5315, doi:10.1016/j.atmosenv.2011.06.056, 2011.

Auvray, M. and Bey, I.: Long-range transport to Europe: Seasonal variations and implications for the European ozone budget, J. Geophys. Res., 110, D11303, doi:10.1029/2004JD005503, 2005.

Bey, I., Jacob, D. J., Yantosca, R. M., Logan, J. A., Field, B., Fiore, A. M., Li, Q., Liu, H., Mickley, L. J., and Schultz, M.: Global modeling of tropospheric chemistry with assimilated meteorology: model description and evaluation, J. Geophys. Res., 106, 23073-23095, doi:10.1029/2001JD000807, 2001.

Bond, T. C., Bhardwaj, E., Dong, R., Jogani, R., Jung, S., Roden, C., Streets, D. G., and Trautmann, N. M.: Historical emissions of black and organic carbon aerosol from energy-related combustion, 1850-2000, Global Biogeochem. Cy., 21, GB2018, doi:10.1029/2006GB002840, 2007.

Camp, C. D., Roulston, M. S., and Yung, Y. L.: Temporal and spatial patterns of the interannual variability of total ozone in the tropics, J. Geophys. Res., 108, 4643, doi:10.1029/2001JD001504, 2003.

Chang, C. P., Zhang, Y., and Li, T.: Interannual and interdecadal variations of the East Asian summer monsoon and tropical Pacific SSTs. Part I: Roles of the subtropical ridge, J. Climate, 13, 4310-4325, doi:10.1175/15200442(2000)013<4310:IAIVOT>2.0.CO;2, 2000.

Chiang, C. K., Fan, J. F., Li, J., and Chang, J. S.: Impact of Asian continental outflow on the springtime ozone mixing ratio in northern Taiwan, J. Geophys. Res., 114, D24304, doi:10.1029/2008JD011322, 2009.

Cooper, O. R., Parrish, D. D., Stohl, A., Trainer, M., Nédélec, P., Thouret, V., Cammas, J. P., Oltmans, S. J., Johnson, B. J., Tarasick, D., Leblanc, T., McDermid, I. S., Jaffe, D., Gao, R., Stith, J., Ryerson, T., Aikin, K., Campos, T., Weinheimer, A., and Avery, M. A.: Increasing springtime ozone mixing ratios in the free troposphere over western North America, Nature, 463, 344-348, doi:10.1038/nature08708, 2010.

Danielsen, E. F. and Mohnen, V. A.: Project Dustorm report: Ozone transport, in situ measurements, and meteorological analyses of tropopause folding, J. Geophys. Res., 82, 5867-5877, doi:10.1029/JC082i037p05867, 1977.

Ding, A. J., Wang, T., Thouret, V., Cammas, J.-P., and Nédélec, P.: Tropospheric ozone climatology over Beijing: analysis of aircraft 
data from the MOZAIC program, Atmos. Chem. Phys., 8, 1-13, doi:10.5194/acp-8-1-2008, 2008a.

Ding, Y., Wang, Z., and Sun, Y.: Inter-decadal variation of the summer precipitation in east China and its association with decreasing Asian summer monsoon. Part I: Observed evidences, Int. J. Climatol., 28, 1139-1161, doi:10.1002/joc.1615, 2008b.

Eckhardt, S., Stohl, A., Wernli, H., James, P., Forster, C., and Spichtinger, N: A 15-year climatology of warm conveyor belts, J. Climate, 17, 218-237, doi:10.1175/15200442(2004)017<0218:AYCOWC>2.0.CO;2, 2004.

Fairlie, T. D., Jacob, D. J., and Park R. J.: The impact of transpacific transport of mineral dust in the United States, Atmos. Environ., 41, 1251-1266, doi:10.1016/j.atmosenv.2006.09.048, 2007.

Fann, N., Lamson, A. D., Anenberg, S. C., Wesson, K., Risley, D., and Hubbell, B. J.: Estimating the national public health burden associated with exposure to ambient $\mathrm{PM}_{2.5}$ and ozone, Risk Anal., 32, 81-95, doi:10.1111/j.1539-6924.2011.01630.x, 2012.

Fiore, A. M., Jacob, D. J., Bey, I., Yantosca, R. M., Field, B. D., Fusco, A. C., and Wilkinson, J. G.: Background ozone over the United States in summer: Origin, trend, and contribution to pollution episodes, J. Geophys. Res., 107, 4275, doi:10.1029/2001JD000982, 2002.

Fu, J. S., Dong, X., Gao, Y., Wong, D. C., and Lam, Y. F.: Sensitivity and linearity analysis of ozone in East Asia: the effects of domestic emission and intercontinental transport, J. Air. Waste. Manage., 62, 1102-1114, doi:10.1080/10962247.2012.699014, 2012.

Fu, Y. and Liao, H.: Simulation of the interannual variations of biogenic emissions of volatile organic compounds in China: impacts on tropospheric ozone and secondary organic aerosol, Atmos. Environ., 59, 170-185, doi:10.1016/j.atmosenv.2012.05.053, 2012.

Fuentes, J. D., Tai, H. R., and Zenker, J.: Ozone impedes the ability of a herbivore to find its host, Environ. Res. Lett., 8, 014048, doi:10.1088/1748-9326/8/1/014048, 2013.

Gao, Y., Fu, J. S., Drake, J. B., Lamarque, J.-F., and Liu, Y.: The impact of emission and climate change on ozone in the United States under representative concentration pathways (RCPs), Atmos. Chem. Phys., 13, 9607-9621, doi:10.5194/acp-13-96072013, 2013.

Guenther, A., Karl, T., Harley, P., Wiedinmyer, C., Palmer, P. I., and Geron, C.: Estimates of global terrestrial isoprene emissions using MEGAN (Model of Emissions of Gases and Aerosols from Nature), Atmos. Chem. Phys., 6, 3181-3210, doi:10.5194/acp-63181-2006, 2006.

Han, J., Shin, B., Lee, M., Hwang, G., Kim, J., Shim, J., Lee, G., and Shim, C.: Variations of surface ozone at Ieodo Ocean Research Station in the East China Sea and the influence of Asian outflows, Atmos. Chem. Phys., 15, 12611-12621, doi:10.5194/acp15-12611-2015, 2015.

Hirahara, S., Ohno, H., Oikawa, Y., and Maeda, S.: Strengthening of the southern side of the jet stream and delayed withdrawal of Baiu season in future climate, J. Meteorol. Soc. Jpn., 90, 663671, doi:10.2151/jmsj.2012-506, 2012.

Huang, M., Carmichael, G. R., Adhikary, B., Spak, S. N., Kulkarni, S., Cheng, Y. F., Wei, C., Tang, Y., Parrish, D. D., Oltmans, S. J., D’Allura, A., Kaduwela, A., Cai, C., Weinheimer, A. J., Wong, M., Pierce, R. B., Al-Saadi, J. A., Streets, D. G., and Zhang, Q.: Impacts of transported background ozone on California air qual- ity during the ARCTAS-CARB period - a multi-scale modeling study, Atmos. Chem. Phys., 10, 6947-6968, doi:10.5194/acp-106947-2010, 2010.

Huang, W. R. and Wang, S. Y. S.: Future changes in propagating and non-propagating diurnal rainfall over East Asia, Clim. Dynam., 1-15, doi:10.1007/s00382-016-3348-4, 2016.

IPCC: Climate Change 2013: The Physical Science Basis. Contribution of Working Group I to the Fifth Assessment Report of the Intergovernmental Panel on Climate Change, edited by: Stocker, T. F., Qin, D., Plattner, G. K., Tignor, M., Allen, S. K., Boschung, J., Nauels, A., Xia, Y., Bex, V., and Midgley, P. M., Cambridge Univ. Press, Cambridge, UK and New York, 1-1535, 2013.

Jacob, D. J., Logan, J. A., and Murti, P. P.: Effect of rising Asian emissions on surface ozone in the United States, Geophys. Res. Lett., 26, 2175-2178, doi:10.1029/1999GL900450, 1999.

Jhun, I., Fann, N., Zanobetti, A., and Hubbell, B.: Effect modification of ozone-related mortality risks by temperature in 97 US cities, Environ. Int., 73, 128-134, doi:10.1016/j.envint.2014.07.009, 2014.

Jiang D. B. and Tian, Z. P.: East Asian monsoon change for the 21st century: Results of CMIP3 and CMIP5 models, Chinese Sci. Bull., 58, 1427-1435, doi:10.1007/s11434-012-5533-0, 2013.

Jiang, H., Liao, H., Pye, H. O. T., Wu, S., Mickley, L. J., Seinfeld, J. H., and Zhang, X. Y.: Projected effect of 2000-2050 changes in climate and emissions on aerosol levels in China and associated transboundary transport, Atmos. Chem. Phys., 13, 7937-7960, doi:10.5194/acp-13-7937-2013, 2013.

Kim, J. H., Lee, H. J., and Lee, S. H.: The characteristics of tropospheric ozone seasonality observed from ozone soundings at Pohang, Korea, Environ. Monit. Assess., 118, 1-12, doi:10.1007/s10661-006-0772-7, 2006.

Kim, M. J., Park, R. J., Ho, C. H., Woo, J. H., Choi, K. C., Song, C. K., and Lee, J. B.: Future ozone and oxidants change under the RCP scenarios, Atmos. Environ., 101, 103-115, doi:10.1016/j.atmosenv.2014.11.016, 2015.

Kurokawa, J., Ohara, T., Uno, I., Hayasaki, M., and Tanimoto, H.: Influence of meteorological variability on interannual variations of springtime boundary layer ozone over Japan during 19812005, Atmos. Chem. Phys., 9, 6287-6304, doi:10.5194/acp-96287-2009, 2009.

Lam, Y. F., Fu, J. S., Wu, S., and Mickley, L. J.: Impacts of future climate change and effects of biogenic emissions on surface ozone and particulate matter concentrations in the United States, Atmos. Chem. Phys., 11, 4789-4806, doi:10.5194/acp-11-47892011, 2011.

Lee, J. B., Cha, J. S., Hong, S. C., Choi, J. Y., Myoung, J. S., Park, R. J., Woo, J. H., Ho, C., Han, J. S., and Song, C. K.: Projections of summertime ozone concentration over East Asia under multiple IPCC SRES emission scenarios, Atmos. Environ., 106, 335-346, doi:10.1016/j.atmosenv.2015.02.019, 2015.

Li, J., Wang, Z., Akimoto, H., Yamaji, K., Takigawa, M., Pochanart, P., Liu, Y., Tanimoto, H., and Kanaya, Y.: Nearground ozone source attributions and outflow in central eastern China during MTX2006, Atmos. Chem. Phys., 8, 7335-7351, doi:10.5194/acp-8-7335-2008, 2008.

Liao, H., Chen, W. T., and Seinfeld, J. H.: Role of climate change in global predictions of future tropospheric ozone and aerosols, J. Geophys. Res., 111, D12304, doi:10.1029/2005JD006852, 2006. 
Lin, J. T., Patten, K. O., Hayhoe, K., Liang, X. Z., and Wuebbles, D. J.: Effects of future climate and biogenic emissions changes on surface ozone over the United States and China, J. Appl. Meteorol. Climatol., 47, 1888-1909, doi:10.1175/2007JAMC1681.1, 2008.

Lin, M., Fiore, A. M., Horowitz, L. W., Cooper, O. R., Naik, V., Holloway, J., Johnson, B. J., Middlebrook, A. M., Oltmans, S. J., Pollack, I. B., Ryerson, T. B., Warner, J. X., Wiedeninmyer, C., Wilson, J., and Wyman, B.: Transport of Asian ozone pollution into surface air over the western United States in spring, J. Geophys. Res., 117, D00V07, doi:10.1029/2011JD016961, 2012.

Lin, M., Horowitz, L. W., Oltmans, S. J., Fiore, A. M., and Fan, S.: Tropospheric ozone trends at Mauna Loa Observatory tied to decadal climate variability, Nat. Geosci., 7, 136-143, doi:10.1038/ngeo2066, 2014.

Lin, M., Horowitz, L. W., Cooper, O. R., Tarasick, D., Conley, S., Iraci, L. T., Johnson, B., Leblanc, T., Petropavlovskikh, I., and Yates, E. L.: Revisiting the evidence of increasing springtime ozone mixing ratios in the free troposphere over western North America, Geophys. Res. Lett., 42, 8719-8728, doi:10.1002/2015GL065311, 2015.

Lin, M., Horowitz, L. W., Payton, R., Fiore, A. M., and Tonnesen, G.: US surface ozone trends and extremes from 1980 to 2014: quantifying the roles of rising Asian emissions, domestic controls, wildfires, and climate, Atmos. Chem. Phys., 17, 29432970, doi:10.5194/acp-17-2943-2017, 2017.

Lin, Y.-K., Lin, T.-H., and Chang, S.-C.: The changes in different ozone metrics and their implications following precursor reductions over northern Taiwan from 1994 to 2007, Environ. Monit. Assess., 169, 143-157, doi:10.1007/s10661-009-1158-4, 2010.

Liu, H., Jacob, D. J., Chan, L. Y., Oltmans, S. J., Bey, I., Yantosca, R. M., Harris, J. M., Duncan, B. N., and Martin, R. V.: Sources of tropospheric ozone along the Asian Pacific Rim: An analysis of ozonesonde observations, J. Geophys. Res., 107, 4573, doi:10.1029/2001JD002005, 2002.

Liu, Q., Lam, K. S., Jiang, F., Wang, T. J., Xie, M., Zhuang, B. L., and Jiang, X. Y.: A numerical study of the impact of climate and emission changes on surface ozone over South China in autumn time in 2000-2050, Atmos. Environ., 76, 227-237, doi:10.1016/j.atmosenv.2013.01.030, 2013.

Liu, X., Chance, K., Sioris, C. E., Kurosu, T. P., Spurr, R. J., Martin, R. V., Fu, T. M., Logan, J. A., Jacob, D. J., Palmer, P. I., Newchurch, M. J., Megretskaia, I. A., Chatfield, R. B.: First directly retrieved global distribution of tropospheric column ozone from GOME: Comparison with the GEOS-Chem model, J. Geophys. Res.-Atmos., 111, D02308, doi:10.1029/2005JD006564, 2006.

Lou, S., Zhu, B., and Liao, H.: Impacts of $\mathrm{O}_{3}$ precursor on surface $\mathrm{O}_{3}$ concentration over China, Chinese Trans, Atmos. Sci., 33, 451-459, 2010.

Lou, S., Liao, H., and Zhu, B.: Impacts of aerosols on surface-layer ozone concentrations in China through heterogeneous reactions and changes in photolysis rates, Atmos. Environ., 85, 123-138, doi:10.1016/j.atmosenv.2013.12.004, 2014.

Lou, S., Liao, H., Yang, Y., and Mu, Q.: Simulation of the interannual variations of tropospheric ozone over China: Roles of variations in meteorological parameters and anthropogenic emissions, Atmos. Environ., 122, 839-851, doi:10.1016/j.atmosenv.2015.08.081, 2015.
Mahlman, S. D. and Moxim, W. J.: Tracer simulation using a global general circulation model: Results from a midlatitude instantaneous source experiment, J. Atmos. Sci., 35, 1340-1374, doi:10.1175/1520-0469(1978)035<1340:TSUAGG>2.0.CO;2, 1978.

McLinden, C. A., Olsen, S. C., Hannegan, B., Wild, O., Prather, M. J., and Sundet, J.: Stratospheric ozone in 3-D models: A simple chemistry and the cross-tropopause flux, J. Geophys. Res., 105, 14653-14665, doi:10.1029/2000JD900124, 2000.

Monks, P. S., Archibald, A. T., Colette, A., Cooper, O., Coyle, M., Derwent, R., Fowler, D., Granier, C., Law, K. S., Mills, G. E., Stevenson, D. S., Tarasova, O., Thouret, V., von Schneidemesser, E., Sommariva, R., Wild, O., and Williams, M. L.: Tropospheric ozone and its precursors from the urban to the global scale from air quality to short-lived climate forcer, Atmos. Chem. Phys., 15, 8889-8973, doi:10.5194/acp-15-8889-2015, 2015.

$\mathrm{Mu}, \mathrm{Q}$. and Liao, H.: Simulation of the interannual variations of aerosols in China: role of variations in meteorological parameters, Atmos. Chem. Phys., 14, 9597-9612, doi:10.5194/acp-149597-2014, 2014.

Nagashima, T., Ohara, T., Sudo, K., and Akimoto, H.: The relative importance of various source regions on East Asian surface ozone, Atmos. Chem. Phys., 10, 11305-11322, doi:10.5194/acp10-11305-2010, 2010.

Olivier, J. G. J. and Berdowski, J. J. M.: Global emissions sources and sinks, edited by: Berdowski, J., Guicherit, R., and Heij, B. J., in: The Climate System, A. A. Balkema Publishers/Swets \& Zeitlinger Publishers, Lisse, The Netherlands, ISBN9058092550, 33-78, 2001.

Ou-Yang, C. F., Hsieh, H. C., Wang, S. H., Lin, N. H., Lee, C. T., Sheu, G. R., and Wang, J. L.: Influence of Asian continental outflow on the regional background ozone level in Northern South China Sea, Atmos. Environ., 78, 144-153, doi:10.1016/j.atmosenv.2012.07.040, 2013.

Park, R. J., Jacob, D. J., Chin, M., and Martin, R. V.: Sources of carbonaceous aerosols over the United States and implications for natural visibility, J. Geophys. Res., 108, 4355, doi:10.1029/2002JD003190, 2003.

Park, R. J., Jacob, D. J., Field, B. D., Yantosca, R. M., and Chin, M.: Natural and transboundary pollution influences on sulfate-nitrate-ammonium aerosols in the United States: implications for policy, J. Geophys. Res., 109, D15204, doi:10.1029/2003JD004473, 2004.

Parrish, D. D., Lamarque, J. F., Naik, V., Horowitz, L., Shindell, D. T., Staehelin, J., Derwent, R., Cooper, O. R., Tanimoto, H., Volz-Thomas, A., Gilge, S., Scheel, H.-E., Steinbacher, M., and Fröhlich, M.: Long-term changes in lower tropospheric baseline ozone concentrations: Comparing chemistry-climate models and observations at northern midlatitudes, J. Geophys. Res., 119, 5719-5736, doi:10.1002/2013JD021435, 2014.

Piccot, S. D., Watson, J. J., and Jones, J. W.: A global inventory of volatile organic compound emissions from anthropogenic sources, J. Geophys. Res., 97, 9897-9912, doi:10.1029/92JD00682, 1992.

Pickering, K. E., Wang, Y. S., Tao, W. K., Price, C., and Muller, J. F.: Vertical distributions of lightning $\mathrm{NO}_{x}$ for use in regional and global chemical transport models, J. Geophys. Res., 103, 3120331216, doi:10.1029/98JD02651, 1998. 
Pochanart, P., Wild, O., and Akimoto, H.: Air pollution import to and export from East Asia, edited by Stohl, A., Hand Book of Environmental Chemistry, Springer, Berlin and Heidelberg, 99130, 2004.

Pochanart, P., Wang, Z., and Akimoto, H.: Boundary Layer Ozone Transport from Eastern China to Southern Japan: Pollution Episodes Observed during Monsoon Onset in 2004, Asian, J. Atmos. Environ., 9, 48-56, doi:10.5572/ajae.2015.9.1.048, 2015.

Price, C. and Rind, D.: A simple lightning parameterization for calculating global lightning distributions, J. Geophys. Res., 97, 9919-9933, doi:10.1029/92JD00719, 1992.

Pye, H. O. T., Liao, H., Wu, S., Mickley, L. J., Jacob, D. J., Henze, D. K., and Seinfeld, J. H.: Effect of changes in climate and emissions on future sulfate-nitrate-ammonium aerosol levels in the United States, J. Geophys. Res., 114, D01205, doi:10.1029/2008JD010701, 2009.

Racherla, P. N. and Adams P. J.: Sensitivity of global tropospheric ozone and fine particulate matter concentrations to climate change, J. Geophys. Res., 111, D24103, doi:10.1029/2005JD006939, 2006.

Racherla, P. N. and Adams, P. J.: US ozone air quality under changing climate and anthropogenic emissions, Environ. Sci. Technol., 43, 571-577, doi:10.1021/es800854f, 2009.

Ren, X., Yang, X., Zhou, T., and Fan, J.: Diagnostic comparison of wintertime East Asian subtropical jet and polar-front jet: Largescale characteristics and transient eddy activities, Acta Meteorol. Sin., 25, 21-33, doi:10.1007/s13351-011-0002-2, 2011.

Rind, D., Lerner, J., Jonas, J., and McLinden, C.: Effects of resolution and model physics on tracer transports in the NASA Goddard Institute for Space Studies general circulation models, J. Geophys. Res., 112, D09315, doi:10.1029/2006JD007476, 2007.

Schnell, J. L., Prather, M. J., Josse, B., Naik, V., Horowitz, L. W., Zeng, G., Shindell, D. T., and Faluvegi, G.: Effect of climate change on surface ozone over North America, Europe, and East Asia, Geophys. Res. Lett., 43, 3509-3518, doi:10.1002/2016GL068060, 2016.

Streets, D. G., Bond, T. C., Carmichael, G. R., Fernandes, S. D., Fu, Q., Klimont, Z., Nelson, S. M., Tsai, N. Y., Wang, M. Q., Woo, J-H., and Yarber, K. F.: An inventory of gaseous and primary aerosol emissions in Asia in the year 2000, J. Geophys. Res, 108, 8809, doi:10.1029/2002JD003093, 2003.

Streets, D. G., Bond, T. C., Lee, T., and Jang, C.: On the future of carbonaceous aerosol emissions, J. Geophys. Res., 109, D24212, doi:10.1029/2004JD004902, 2004.

Strode, S. A., Rodriguez, J. M., Logan, J. A., Cooper, O. R., Witte, J. C., Lamsal, L. N., Damon, M., Van Aartsen, B., Steenrod, S. D., and Strahan, S. E.: Trends and variability in surface ozone over the United States, J. Geophys. Res.-Atmos., 120, 9020-9042, doi:10.1002/2014JD022784, 2015.

Sun, F. H., Zhang, Y. C., and Guo, L. L.: Relationship between the East Asia subtropical westerly jet anomaly and summer precipitation over eastern China, Plateau Meteorology, 28, 1308-1315, 2009.

Tai, A. P. K., Val Martin, M., and Heald, C. L.: Threat to future global food security from climate change and ozone air pollution, Nature Climate Change, 4, 817-821, doi:10.1038/nclimate2317, 2014.
Tang, G., Li, X., Wang, Y., Xin, J., and Ren, X.: Surface ozone trend details and interpretations in Beijing, 2001-2006, Atmos. Chem. Phys., 9, 8813-8823, doi:10.5194/acp-9-8813-2009, 2009.

Tanimoto, H.: Increase in springtime tropospheric ozone at a mountainous site in Japan for the period 1998-2006, Atmos. Environ., 43, 1358-1363, doi:10.1016/j.atmosenv.2008.12.006, 2009.

Tanimoto, H., Sawa, Y., Matsueda, H., Uno, I., Ohara, T., Yamaji, K., Kurokawa, J., and Yonemura, S.: Significant latitudinal gradient in the surface ozone spring maximum over East Asia. Geophys. Res. Lett., 32, L21805, doi:10.1029/2005GL023514, 2005.

Tanimoto, H., Ohara, T., and Uno, I.: Asian anthropogenic emissions and decadal trends in springtime tropospheric ozone over Japan: 1998-2007, Geophys. Res. Lett., 36, L23802, doi:10.1029/2009GL041382, 2009.

Tanimoto, H., Zbinden, R. M., Thouret, V., and Nédélec, P.: Consistency of tropospheric ozone observations made by different platforms and techniques in the global databases, Tellus B, 67, 27073, doi:10.3402/tellusb.v67.27073, 2015.

Terao, Y., Logan, J. A., Douglass, A. R., and Stolarski, R. S.: Contribution of stratospheric ozone to the interannual variability of tropospheric ozone in the northern extratropics, J. Geophys. Res., 113, D18309, doi:10.1029/2008JD009854, 2008.

Val Martin, M., Heald, C. L., Lamarque, J.-F., Tilmes, S., Emmons, L. K., and Schichtel, B. A.: How emissions, climate, and land use change will impact mid-century air quality over the United States: a focus on effects at national parks, Atmos. Chem. Phys., 15, 2805-2823, doi:10.5194/acp-15-2805-2015, 2015.

van der Werf, G. R., Randerson, J. T., Giglio, L., Collatz, G. J., Mu, M., Kasibhatla, P. S., Morton, D. C., DeFries, R. S., Jin, Y., and van Leeuwen, T. T.: Global fire emissions and the contribution of deforestation, savanna, forest, agricultural, and peat fires (19972009), Atmos. Chem. Phys., 10, 11707-11735, doi:10.5194/acp10-11707-2010, 2010.

van Donkelaar, A., Martin, R. V., Leaitch, W. R., Macdonald, A. M., Walker, T. W., Streets, D. G., Zhang, Q., Dunlea, E. J., Jimenez, J. L., Dibb, J. E., Huey, L. G., Weber, R., and Andreae, M. O.: Analysis of aircraft and satellite measurements from the Intercontinental Chemical Transport Experiment (INTEX-B) to quantify long-range transport of East Asian sulfur to Canada, Atmos. Chem. Phys., 8, 2999-3014, doi:10.5194/acp-8-2999-2008, 2008.

Voulgarakis, A., Marlier, M. E., Faluvegi, G., Shindell, D. T., Tsigaridis, K., and Mangeon, S.: Interannual variability of tropospheric trace gases and aerosols: The role of biomass burning emissions, J. Geophys. Res., 120, 7157-7173, doi:10.1002/2014JD022926, 2015.

Walker, T. W., Martin, R. V., van Donkelaar, A., Leaitch, W. R., MacDonald, A. M., Anlauf, K. G., Cohen, R. C., Bertram, T. H., Huey, L. G., Avery, M. A., Weinheimer, A. J., Flocke, F. M., Tarasick, D. W., Thompson, A. M., Streets, D. G., and Liu, X.: TransPacific transport of reactive nitrogen and ozone to Canada during spring, Atmos. Chem. Phys., 10, 8353-8372, doi:10.5194/acp10-8353-2010, 2010.

Wang, K., Zhang, Y., Jang, C., Phillips, S., and Wang, B.: Modeling intercontinental air pollution transport over the transPacific region in 2001 using the Community Multiscale Air Quality modeling system, J. Geophys. Res., 114, D04307, doi:10.1029/2008JD010807, 2009a. 
Wang, M.: Atmospheric Chemistry (second edition), Meteorological Press of China, Beijing, China, 343 pp., 1999.

Wang, T., Wei, X. L., Ding, A. J., Poon, C. N., Lam, K. S., Li, Y. S., Chan, L. Y., and Anson, M.: Increasing surface ozone concentrations in the background atmosphere of Southern China, 19942007, Atmos. Chem. Phys., 9, 6217-6227, doi:10.5194/acp-96217-2009, 2009b.

Wang, Y., Jacob, D. J., and Logan, J. A.: Global Simulation of tropospheric $\mathrm{O}_{3}-\mathrm{NO}_{x}$-hydrocarbon chemistry: 1. Model formulation, J. Geophys. Res., 103, 10713-10725, doi:10.1029/98JD00158, 1998.

Wang, Y., Zhang, Y., Hao, J., and Luo, M.: Seasonal and spatial variability of surface ozone over China: contributions from background and domestic pollution, Atmos. Chem. Phys., 11, 35113525, doi:10.5194/acp-11-3511-2011, 2011.

Wang, Y., Konopka, P., Liu, Y., Chen, H., Müller, R., Plöger, F., Riese, M., Cai, Z., and Lü, D.: Tropospheric ozone trend over Beijing from 2002-2010: ozonesonde measurements and modeling analysis, Atmos. Chem. Phys., 12, 8389-8399, doi:10.5194/acp-12-8389-2012, 2012.

Wang, Y., Shen, L., Wu, S., Mickley, L., He, J., and Hao, J.: Sensitivity of surface ozone over China to 2000-2050 global changes of climate and emissions, Atmos. Environ., 75, 374-382, doi:10.1016/j.atmosenv.2013.04.045, 2013.

Wild, O., Fiore, A. M., Shindell, D. T., Doherty, R. M., Collins, W. J., Dentener, F. J., Schultz, M. G., Gong, S., MacKenzie, I. A., Zeng, G., Hess, P., Duncan, B. N., Bergmann, D. J., Szopa, S., Jonson, J. E., Keating, T. J., and Zuber, A.: Modelling future changes in surface ozone: a parameterized approach, A tmos. Chem. Phys., 12, 2037-2054, doi:10.5194/acp-12-2037-2012, 2012.

Wilkinson, S., Mills, G., Illidge, R., and Davies, W. J.: How is ozone pollution reducing our food supply?, J. Exp. Bot., 63, 527-536, doi:10.1093/jxb/err317, 2011.

Wu, S., Mickley, L. J., Jacob, D. J., Rind, D., and Streets, D. G.: Effects of 2000-2050 changes in climate and emissions on global tropospheric ozone and the policy-relevant background surface ozone in the United States, J. Geophys. Res., 113, D18312, doi:10.1029/2007JD009639, 2008a.

Wu, S., Mickley, L. J., Leibensperger, E. M., Jacob, D. J., Rind, D., and Streets, D. G.: Effects of 2000-2050 global change on ozone air quality in the United States, J. Geophys. Res., 113, D06302, doi:10.1029/2007JD008917, 2008b.

$\mathrm{Xu}, \mathrm{W}$., Lin, W., Xu, X., Tang, J., Huang, J., Wu, H., and Zhang, $\mathrm{X}$.: Long-term trends of surface ozone and its influencing factors at the Mt Waliguan GAW station, China - Part 1: Overall trends and characteristics, Atmos. Chem. Phys., 16, 6191-6205, doi:10.5194/acp-16-6191-2016, 2016.

Xu, X., Lin, W., Wang, T., Yan, P., Tang, J., Meng, Z., and Wang, Y.: Long-term trend of surface ozone at a regional background station in eastern China 1991-2006: enhanced variability, Atmos. Chem. Phys., 8, 2595-2607, doi:10.5194/acp-8-2595-2008, 2008.

Yang, Y., Liao, H., and Li, J.: Impacts of the East Asian summer monsoon on interannual variations of summertime surfacelayer ozone concentrations over China, Atmos. Chem. Phys., 14, 6867-6879, doi:10.5194/acp-14-6867-2014, 2014.
Yang, Y., Liao, H., and Lou, S.: Decadal trend and interannual variation of outflow of aerosols from East Asia: Roles of variations in meteorological parameters and emissions, Atmos. Environ., 100, 141-153, doi:10.1016/j.atmosenv.2014.11.004, 2015.

Yienger, J. J. and Levy, H.: Empirical model of global soilbiogenic $\mathrm{NO}_{x}$ emissions, J. Geophys. Res., 100, 11447-11464, doi:10.1029/95JD00370, 1995.

Young, P. J., Archibald, A. T., Bowman, K. W., Lamarque, J.-F., Naik, V., Stevenson, D. S., Tilmes, S., Voulgarakis, A., Wild, O., Bergmann, D., Cameron-Smith, P., Cionni, I., Collins, W. J., Dalsøren, S. B., Doherty, R. M., Eyring, V., Faluvegi, G., Horowitz, L. W., Josse, B., Lee, Y. H., MacKenzie, I. A., Nagashima, T., Plummer, D. A., Righi, M., Rumbold, S. T., Skeie, R. B., Shindell, D. T., Strode, S. A., Sudo, K., Szopa, S., and Zeng, G.: Preindustrial to end 21st century projections of tropospheric ozone from the Atmospheric Chemistry and Climate Model Intercomparison Project (ACCMIP), Atmos. Chem. Phys., 13, 2063 2090, doi:10.5194/acp-13-2063-2013, 2013.

Yue, X. and Unger, N.: Ozone vegetation damage effects on gross primary productivity in the United States, Atmos. Chem. Phys. 14, 9137-9153, doi:10.5194/acp-14-9137-2014, 2014.

Zhang, L., Jacob, D. J., Boersma, K. F., Jaffe, D. A., Olson, J. R., Bowman, K. W., Worden, J. R., Thompson, A. M., Avery, M. A., Cohen, R. C., Dibb, J. E., Flock, F. M., Fuelberg, H. E., Huey, L. G., McMillan, W. W., Singh, H. B., and Weinheimer, A. J.: Transpacific transport of ozone pollution and the effect of recent Asian emission increases on air quality in North America: an integrated analysis using satellite, aircraft, ozonesonde, and surface observations, Atmos. Chem. Phys., 8, 6117-6136, doi:10.5194/acp-8-6117-2008, 2008.

Zhang, Q., Streets, D. G., Carmichael, G. R., He, K. B., Huo, H., Kannari, A., Klimont, Z., Park, I. S., Reddy, S., Fu, J. S., Chen, D., Duan, L., Lei, Y., Wang, L. T., and Yao, Z. L.: Asian emissions in 2006 for the NASA INTEX-B mission, Atmos. Chem. Phys., 9, 5131-5153, doi:10.5194/acp-9-5131-2009, 2009.

Zhang, Q., Yuan, B., Shao, M., Wang, X., Lu, S., Lu, K., Wang, M., Chen, L., Chang, C.-C., and Liu, S. C.: Variations of ground-level $\mathrm{O}_{3}$ and its precursors in Beijing in summertime between 2005 and 2011, Atmos. Chem. Phys., 14, 6089-6101, doi:10.5194/acp-14-6089-2014, 2014.

Zhang, Y. C. and Guo, L. L.: Multi-model ensemble simulated changes in the subtropical westerly jet over east Asia under the global warming condition, Scientia Meteorologica Sinica, 30, 694-700, 2010.

Zhou, D., Ding, A., Mao, H., Fu, C., Wang, T., Chan, L. Y., Ding, K., Zhang, Y., Liu J., Lu, A., and Hao, N.: Impacts of the East Asian monsoon on lower tropospheric ozone over coastal South China, Environ. Res. Lett., 8, 044011, doi:10.1088/17489326/8/4/044011, 2013.

Zhu, J. and Liao, H.: Future ozone air quality and radiative forcing over China owing to future changes in emissions under the Representative Concentration Pathways (RCPs), J. Geophys. Res.Atmos., 121, 1978-2001, doi:10.1002/2015JD023926, 2016.

Zhu, J. L., Liao, H., and Li, J. P.: Increases in aerosol concentrations over eastern China due to the decadal-scale weakening of the East Asian summer monsoon, Geophys. Res. Lett., 39, L09809, doi:10.1029/2012g1051428, 2012. 